Nevada

Environmental

Restoration

Project

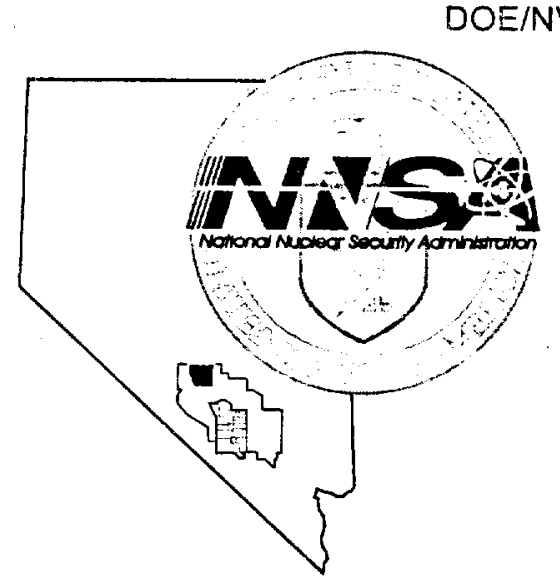

Streamlined Approach for

Environmental Restoration Plan for Corrective Action Unit 499: Hydrocarbon Spill Site, Tonopah Test Range, Nevada

Controlled Copy No::

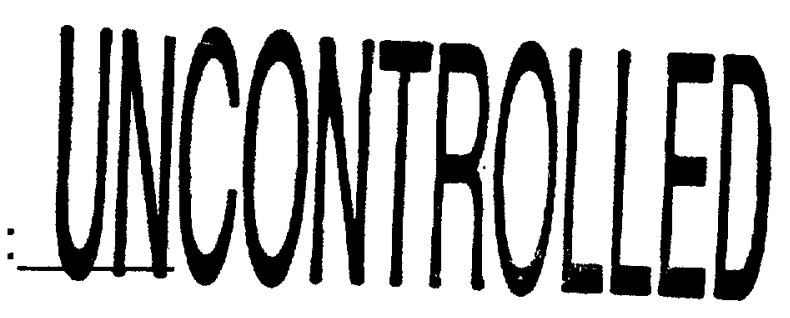

Revision: 0

September 2001

Environmental Restoration

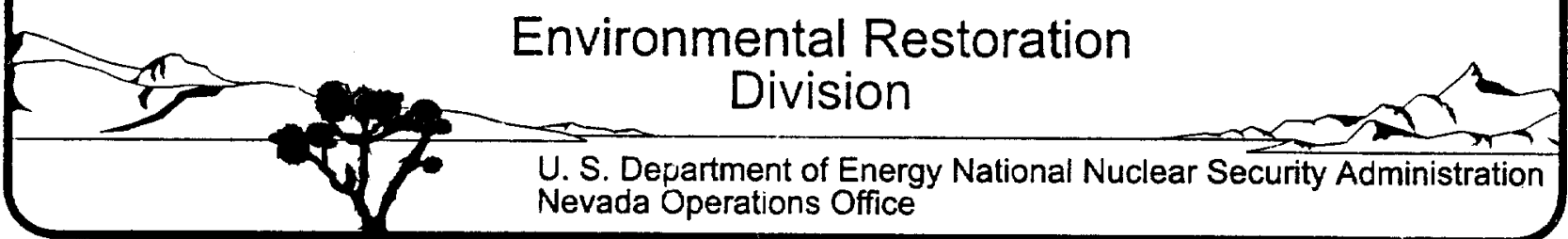




\section{DISCLAIMER STATEMENT}

Reference herein to any specific commercial product, process, or service by trade name, trademark, manufacturer, or otherwise, does not necessarily constitute or imply its endorsement, recommendation, or favoring by the U.S. Government or any agency thereof or its contractors or subcontractors.

\section{AVAILABILITY STATEMENT}

Available for sale to the public from-

U.S. Department of Commerce

National Technical Information Service

5285 Port Royal Road

Springfield, VA 22161-0002

Telephone: 800.553 .6847

Fax: 703.605.6900

E-mail: orders@ntis.fedworld.gov

Online ordering: http://www.ntis.gov/ordering.htm

Available electronically at http://www.doe.gov/bridge

Available for a processing fee to U.S. Department of Energy and its contractors, in paper, fromU.S. Department of Energy

Office of Scientific and Technical Information

P.O. Box 62

Oak Ridge, TN 37831-0062

Telephone: 865.576 .8401

Fax: 865.576.5728

E-mail: reports@adonis.osti.gov 


\title{
STREAMLINED APPROACH FOR ENVIRONMENTAL RESTORATION PLAN FOR CORRECTIVE ACTION UNIT 499: HYDROCARBON SPILL SITE, TONOPAH TEST RANGE, NEVADA
}

\author{
Prepared for: \\ U.S. Department of Energy \\ National Nuclear Security Administration \\ Nevada Operations Office \\ Under Contract No. DE-AC08-96-NV11718
}

Controlled Copy No.

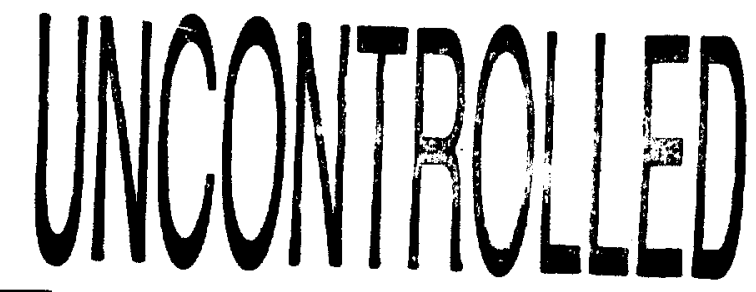

Revision: 0

September 2001 



\section{STREAMLINED APPROACH FOR ENVIRONMENTAL RESTORATION PLAN FOR CORRECTIVE ACTION UNIT 499: HYDROCARBON SPILL SITE, TONOPAH TEST RANGE, NEVADA}

Approved by:

Janet L. Appenzeller-Wing, Project Manager Industrial Sites Project

Approved by:

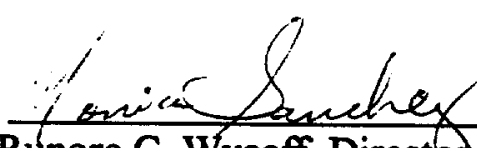

Runore C. Wycoff, Directod Nevada Environmental Restoration Project
Date: $2 \cdot 2 /-01$

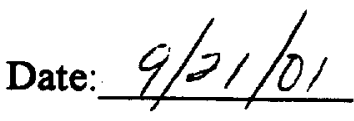


THIS PAGE INTENTIONALLY LEFT BLANK 


\section{TABLE OF CONTENTS}

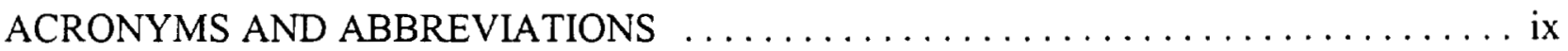

EXECUTIVE SUMMARY $\ldots \ldots \ldots \ldots \ldots \ldots \ldots \ldots \ldots \ldots \ldots \ldots \ldots \ldots \ldots \ldots \ldots$

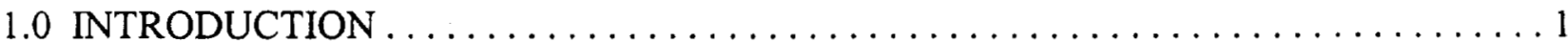

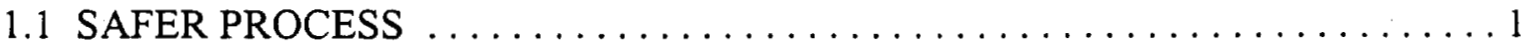

1.2 SUMMARY OF PROPOSED CORRECTIVE ACTION $\ldots \ldots \ldots \ldots \ldots \ldots . ., \ldots$

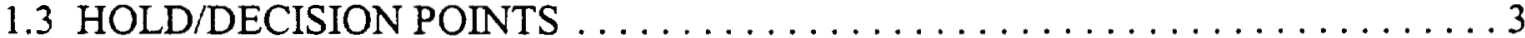

1.4 SAFER WORK PLAN CONTENTS $\ldots \ldots \ldots \ldots \ldots \ldots \ldots \ldots \ldots \ldots$

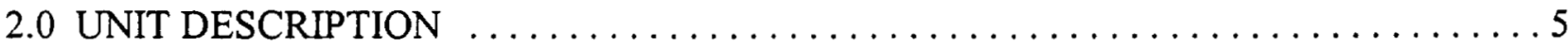

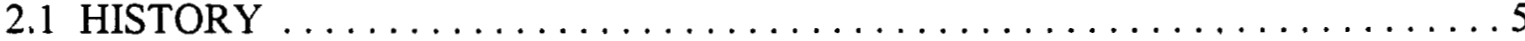

2.1.1 RG-25-001-RD24: Radar 24 Diesel Spill Site (Nevada Division of Emergency Management [NDEM] \#980326-2728) .............5

2.2 SITE LOCATION AND DESCRIPTION $\ldots \ldots \ldots \ldots \ldots \ldots \ldots \ldots \ldots$

2.2.1 CAS RG-25-001-RD24: Radar 24 Diesel Spill Site

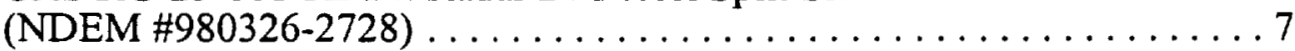

2.3 PROCESS KNOWLEDGE ................................ 8

2.3.1 CAS RG-25-001-RD24: Radar 24 Diesel Spill Site

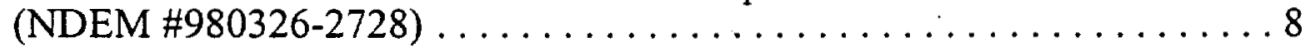

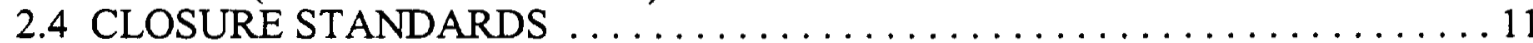

3.0 FIELD ACTIVITIES AND CLOSURE OBJECTIVES $\ldots \ldots \ldots \ldots \ldots \ldots \ldots \ldots$

3.1 CONSTITUENTS OF POTENTIAL CONCERN $\ldots \ldots \ldots \ldots \ldots \ldots \ldots \ldots$

3.1.1 CAS RG-25-001-RD24: Radar 24 Diesel Spill Site ..............13

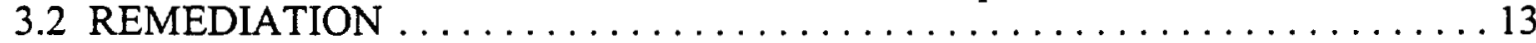

3.2.1 CAS RG-25-001-RD24: Radar 24 Diesel Spill Site $\ldots \ldots \ldots \ldots \ldots \ldots 13$

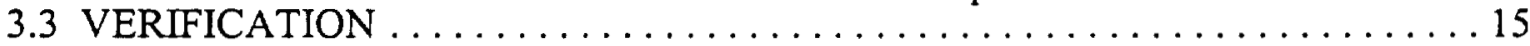

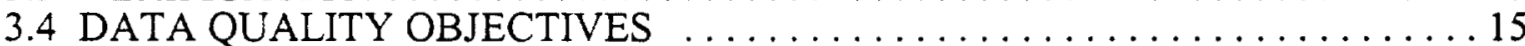

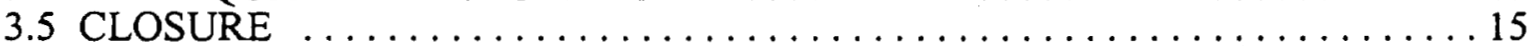

3.5.1 CAS RG-25-001-RD24: Radar 24 Diesel Spill Site ............ 15

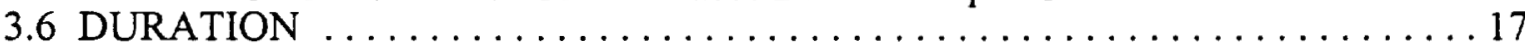

4.0 REPORTS AND RECORDS AVAILABILITY ....................... 19

5.0 INVESTIGATION/REMEDIATION WASTE MANAGEMENT $\ldots \ldots \ldots \ldots \ldots \ldots .21$

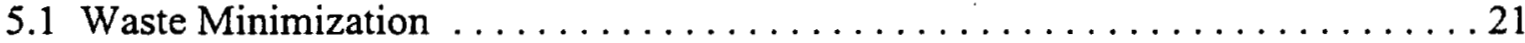

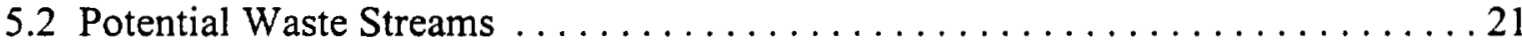

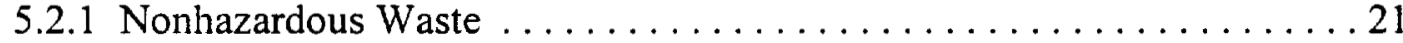

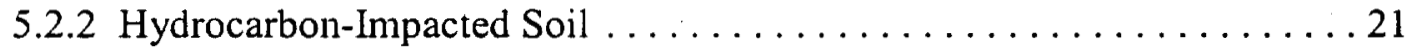

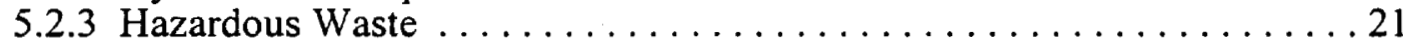

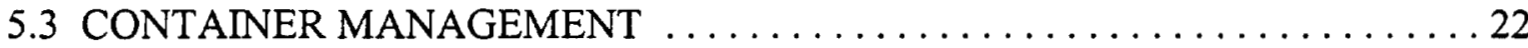

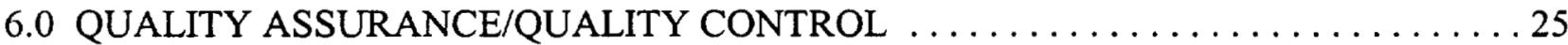

6.1 PROPOSED FIELD SAMPLE COLLECTION ACTIVITIES $\ldots \ldots \ldots \ldots \ldots 25$

6.2 PROPOSED LABORATORY/ANALYTICAL DATA QUALITY

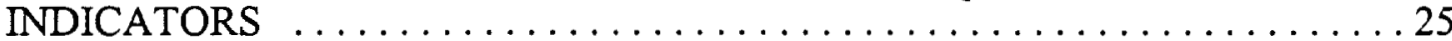

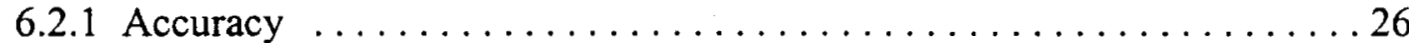

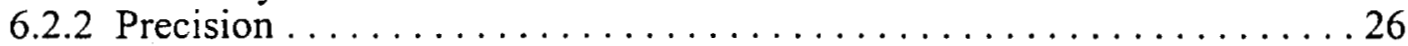




\section{TABLE OF CONTENTS (continued)}

6.2 .3 Representativeness . . . . . . . . . . . . . . . . . . . 26

6.2 .4 Completeness . . . . . . . . . . . . . . . . . . . . . . . . . . . . . . . 29

6.2 .5 Comparability . . . . . . . . . . . . . . . . . . . . . . . 29

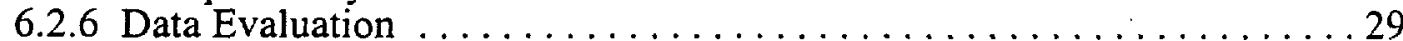

6.2 .7 Quality Control Samples ... . . . . . . . . . . . . . . . . . . . . . 29

6.2 .8 Laboratory Quality Control Samples . . . . . . . . . . . . . . 30

7.0 REFERENCES

\section{APPENDICES}

APPENDIX A-1 DATA QUALITY OBJECTIVES

APPENDIX A-2 PROJECT ORGANIZATION

APPENDIX A-3 SPILI NOTIFICATION FOR BUILDING 24-50 AT TTR

DISTRIBUTION LIST

\section{FIGURES}

FIGURE 1 LOCATION OF CAU 499: HYDROCARBON SPILL SITE, TTR . . . . . . . 2

FIGURE 2 CAS RG-25-001-RD24 RADAR 24 DIESEL SPILL SITE LOCATION . . . . . . 6

FIGURE 3 CAS RG-25-001-RD24 RADAR 24 DIESEL SPILL SITE CONCEPTUAL SITE MODEL CROSS SECTION $\ldots \ldots \ldots \ldots \ldots \ldots \ldots \ldots \ldots \ldots$

FIGURE 4 RG-25-001-RD24 RADAR 24 DIESEL SPILL SITE ALTERNATE CONCEPTUAL SITE MODEL CROSS SECTION $\ldots \ldots \ldots \ldots \ldots \ldots \ldots \ldots$

FIGURE 5 CAU 499 PROPOSED CLOSURE SCHEDULE $\ldots \ldots \ldots \ldots \ldots \ldots \ldots \ldots$

\section{TABLES}

TABLE 1 - SAMPLE ANALYTICAL RESULTS FROM CAS RG-25-001-RD24 . . . . . . . . 7

TABLE 2 - VERIFICATION SOIL SAMPLING REQUIREMENTS FOR CAU $499 \ldots \ldots$. . 16

TABLE 3 - POTENTIAL WASTE STREAMS AT CAU $499 \ldots \ldots \ldots \ldots \ldots \ldots \ldots \ldots$ 


\section{TABLE OF CONTENTS (continued)}

TABLE 4 - MANAGEMENT OF VARIOUS WASTE TYPES TO BE PRODUCED AT CAU 499 CLOSURE . . . . . . . . . . . . . . . . . . . . . . . . 22

TABLE 5 - LABORATORY/ANALYTICAL DATA QUALITY INDICATORS . . . . . . . . 27

TABLE 6 - LABORATORY TOTAL PETROLEUM HYDROCARBON PROCEDURE FOR

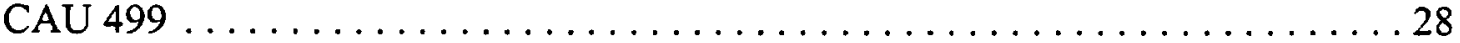




\section{ACRONYMS AND ABBREVIATIONS}

$\% \mathrm{R} \quad$ Percent recovery

AST Above-ground storage tank

bgs Below ground surface

BN Bechtel Nevada

CAI Corrective Action Investigation

CAS Corrective Action Site

CAU Corrective Action Unit

CLP Contract laboratory protocol

COC Constituent of concern

COPC Constituent of potential concern

CR Closure Report

CSM Conceptual Site Model

DOE U.S. Department of Energy

DOE/NV U.S. Department of Energy Nevada, Operations Office

DQO Data Quality Objectives

DQI Data Quality Indicator(s)

EPA U.S. Environmental Protection Agency

FFACO Federal Facility Agreement and Consent Order

ft foot (feet)

gal gallon

IT International Technology Corp

L liter

m meter

$\mathrm{m}^{3} \quad$ cubic meters

$\mathrm{mg} / \mathrm{kg} \quad$ milligram per kilogram 


\section{ACRONYMS AND ABBREVIATIONS (continued)}

$\mathrm{mg} / \mathrm{L} \quad$ milligram per liter

MS/MSD Matrix Spike/Matrix Spike Duplicate

NAC Nevada Administrative Code

NDEM Nevada Division of Emergency Management

NDEP Nevada Division of Environmental Protection

NNSA/NV National Nuclear Security Administration Nevada Operations Office

NTS Nevada Test Site

PPE Personal protective equipment

ppm Parts per million

QA Quality Assurance

QC Quality Control

RCRA Resource Conservation and Recovery Act

RPD Relative Percent Difference

SAA Satellite Accumulation Area

SAFER Streamlined Approach for Environmental Restoration

SD Standard deviation

SDG Sample Delivery Group

TPH Total petroleum hydrocarbons

TTR Tonopah Test Range

$\mathrm{yd}^{3} \quad$ cubic yards 


\section{EXECUTIVE SUMMARY}

This plan addresses closure of Corrective Action Unit (CAU) 499 identified as Hydrocarbon Spill Site, Tonopah Test Range (TTR) in Appendix III of the Federal Facility Agreement and Consent Order (FFACO, 1996 as amended). CAU 499 is located on the TTR in Nevada and consists of the following single Corrective Action Site (CAS).

- CAS RG-25-001-RD24 - Radar 24 Diesel Spill Site is a diesel fuel release associated with a 3,785-liter (L) (1,000-gallon [gal]) above-ground storage tank (AST) that was in service for 30 years. The original 3,785-L (1,000-gal) AST was replaced by a 1,003-L (265-gal) double-walled AST in 1992. In 1998 a non-reportable release of diesel fuel (less than $3.8 \mathrm{~L}$ ) occurred while servicing the tank. During clean-up activities, it was discovered that previous undocumented releases had occurred impacting the soil area under the AST. A Spill Notification was filed with the Nevada Division of Emergency Management, \#980326-2728 (Appendix A-3). The AST was moved from the north side onto a concrete pad on the east side of Building 24-50. The impacted soil is located on the north side of Building 24-50 below the previous location of the AST. The impacted soil is suspected to have resulted from numerous small over filling or gauge spills over the operational life of the AST. CAS RG-25-001-RD24 is located on the north side of Building 24-50 on the TTR approximately 4.0 kilometers (2.5 miles) southwest of the Area 3 Compound at the end of the Avenue 24.

Closure of CAU 499 will be completed by the following:

- CAS RG-25-001-RD24, Radar 24 Diesel Spill Site - Determine the lateral and vertical extent of the soil impacted by the petroleum hydrocarbons. A Geoprobe and/or a backhoe, and petroleum hydrocarbon field screening test kits will be used to determine the extent of the hydrocarbon-impacted soil, and if hydrocarbons have reached the bedrock. If only soil has been impacted, then the site will be clean closed by excavation and disposal of the impacted soil in the Nevada Test Site Area 6 Hydrocarbon Landfill. Soil samples will be collected from the bottom and sidewalls of the excavation to verify that all hydrocarbon- impacted soil has been removed. The excavation will then be backfilled with clean material.

- If the bedrock or soil under Building 24-50 has been impacted, then the accessible impacted soil will be removed and the impacted bedrock and inaccessible soil left in place. Soil samples will be collected from the bottom and sidewalls of the excavation to determine the level of hydrocarbon-impacted material left in place. Sampling results will then be evaluated against the A through K criteria (Nevada Administrative Code, 2000) to determine if the site can be administratively closed in place. The excavation will then be backfilled with clean material. 
THIS PAGE INTENTIONALLY LEFT BLANK 


\subsection{INTRODUCTION}

This Streamlined Approach for Environmental Restoration (SAFER) plan addresses the action necessary for the closure of Corrective Action Unit (CAU) 499, Hydrocarbon Spill Site, Tonopah Test Range (TTR). This CAU is currently listed in Appendix III of the Federal Facility Agreement and Consent Order (FFACO) (FFACO, 1996). CAU 499 is located on the TTR and consists of the following single Corrective Action Site (CAS) (Figure 1):

- $\quad$ CAS RG-25-001-RD24 - Radar 24 Diesel Spill Site is a diesel fuel release site that is assumed to have been cased by numerous small historical over fillings, spills and leaks from an above-ground storage tank (AST) over a period of 36 years. The tank was located on the north side of Building $24-50$ on the TTR approximately 4.0 kilometers (2.5 miles) southwest of the Area 3 Compound at the end of the Avenue 24.

\subsection{SAFER PROCESS}

The SAFER process will be employed at CAUs where the parties agree that enough information exists about the nature and extent of contamination to propose an appropriate corrective action prior to the completion of a Corrective Action Investigation (CAI).

The SAFER process combines elements of the Data Quality Objectives (DQO) process and the observational approach to help plan and conduct corrective actions. DQOs are used to identify the problem and define the type and quality of data needed to complete the investigation phase of the process. The observational approach provides a framework for managing uncertainty and planning decision making. The purpose of the investigation in the SAFER process is to verify the adequacy of existing information to implement the corrective action.

Use of the SAFER concept allows for technical decisions to be made based on incomplete, but sufficient information and the experience of the decision maker. Any uncertainties are addressed by documented assumptions that are verified by sampling and analyses, data evaluation and onsite observations as planned activities progress and by contingency plans, as necessary. The remediation and closure may proceed simultaneously with site characterization as sufficient data are gathered to confirm or disprove the assumptions made in selecting the closure method. If at any time during the site closure new information is developed that indicates that the closure method should be revised, the closure activities will be modified to implement the revised closure method.

Closure of CAU 499 will consist primarily of removal of hydrocarbon-impacted soil. The extent of impacted soil will be determined by the use of a Geoprobe or backhoe and the use of total petroleum hydrocarbon (TPH) field screening test kits. Verification samples will be collected and analyzed by an off-site laboratory to demonstrate clean closure of the site. If during the CAI process TPH impacted soil is discovered down to the soil/bedrock interface, characterization activities will not be conducted into the bedrock. In addition, if hydrocarbon-impacted soil extends under Building 24-50, this soil will be left in place. The appropriate corrective action will be determined prior to completing the CAI. 


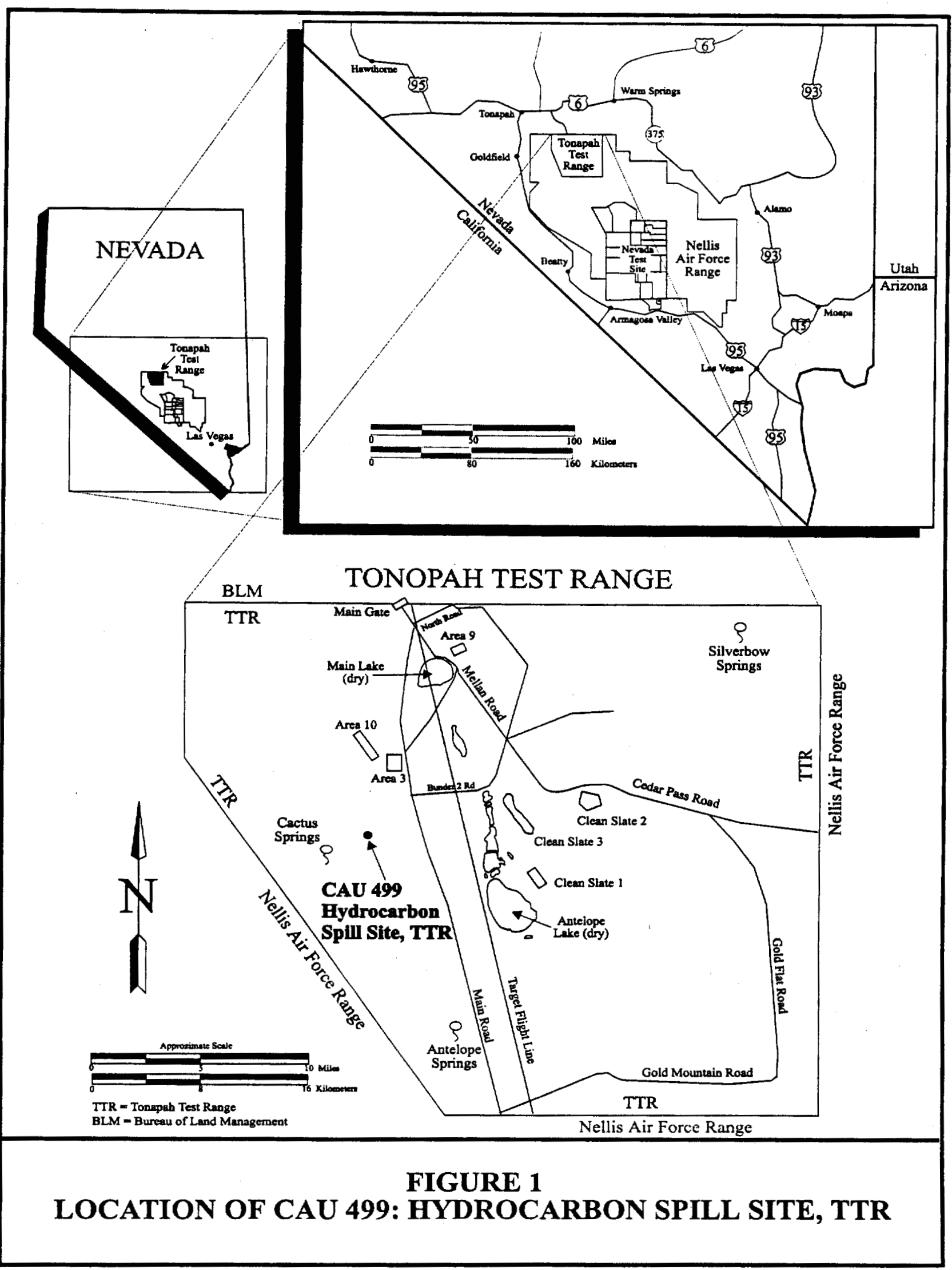




\subsection{SUMMARY OF PROPOSED CORRECTIVE ACTION}

Closure for CAU 499 will be completed by the following:

- CAS RG-25-001-RD24 - Radar 24 Diesel Spill Site. The lateral and vertical extent of the petroleum hydrocarbon- impacted soil will be determined. A Geoprobe and/or a backhoe, and petroleum field screening kits will be used to determine the extent of the hydrocarbon-impacted soil and the depth to bedrock. If only accessible soil has been impacted, then the site will be clean closed by excavation and disposal of the TPH impacted soil in the Nevada Test Site (NTS) Area 6 Hydrocarbon Landfill. If the bedrock or the soil under Building 24-50 has been impacted, then the site will be closed in place. The accessible diesel impacted soil will be excavated and disposed of while leaving the impacted bedrock and inaccessible soil in place. Sampling results will then be evaluated against the "A through K" criteria (Nevada Administrative Code [NAC], 2000) to determine if implementation of a Use Restriction will adequately protect human health and environment, i.e., if the site can be closed in place. Nevada Division of Environmental Protection (NDEP) approval of the SAFER Closure Report (CR), including the A-K Checklist will then be obtained.

\section{$1.3 \mathrm{HOLD} / \mathrm{DECISION}$ POINTS}

During closure activities, certain conditions affecting the project schedule and budget may require decisions to be made prior to continuing work. Work stoppage conditions may include:

- Finding any unsafe condition or work practice that poses a threat to people, equipment, or the environment that was not originally documented with plans for its control in the SiteSpecific Health and Safety Plan.

- Equipment access, operation, and mobility around Building 24-50 can be effected by TTR site operations and security constraints.

- Out-of-scope work activities such as the detection of other constituents of concern (COCs), the size of the release is considerably larger than planned, and other technical factors requiring the preparation of a Record of Technical Change.

If any of these conditions occur, work will stop and the U.S. Department of Energy (DOE), National Nuclear Security Administration Nevada Operations Office (NNSA/NV) and/or the NDEP will be notified. Work will continue when a resolution has been agreed upon and a Record of Technical Change has been approved.

\subsection{SAFER WORK PLAN CONTENTS}

This SAFER Plan has been developed to support the proposed characterization and closure of CAU 499. The format of the plan is:

- Introduction (Section 1.0)

- Unit Description (Section 2.0) 
- Field Activities and Closure Objectives (Section 3.0)

- Reports and Records Availability (Section 4.0)

- Investigation/Remediation Waste Management (Section 5.0)

- Quality Assurance/Quality Control (Section 6.0)

- References (Section 7.0)

This plan was developed using information and guidance provided from the following documents:

Federal Facility Agreement and Consent Order (FFACO) of 1996, Nevada Division of Environmental Protection, U.S. Department of Energy, and U.S. Department of Defense, April 1996.

Occupational Safety and Health Administration, 2001, Title 29 Code of Federal Regulations 1910.120, Hazardous Waste Operations and Emergency Response, Washington, D.C.

U.S. Department of Energy, Nevada Operations Office. 1994. Nevada Environmental Restoration Project. Project Management Plan, Revision 0.

U.S. Department of Energy, Nevada Operations Office. 1996. Industrial Sites Quality Assurance Project Plan, Nevada Test, Nevada, Rev. 1, DOE/NV-372.

U.S. Environmental Protection Agency. 2000. Guidance for the Data Quality Objective Process EPA QA/G-4, EPA/600/R96-055, Washington, D.C. 


\subsection{UNIT DESCRIPTION}

CAU 499 Hydrocarbon Spill Site, TTR is located adjacent to Building 24-50 (Figure 1) on the TTR. CAS RG-25-001-RD24 - Radar 24 Diesel Spill Site, is located on the north side of Building 24-50 approximately 4.0 kilometers (2.5 miles) southwest of the Area 3 Compound at the end of the Avenue 24.

\subsection{HISTORY}

\subsubsection{RG-25-001-RD24: Radar 24 Diesel Spill Site (Nevada Division of Emergency Management [NDEM] \#980326-2728)}

CAS RG-25-001-RD24, Radar 24 Diesel Spill Site (Figure 2), is located on the north side of Building 24-50 on the TTR. The site was the former location of a 3,785-liter (L) (1,000-gallon [gal]) AST that supplied diesel fuel to an emergency generator at the site from the early 1960s until approximately 1992. In 1992, the 3,785-L (1,000-gal) AST was replaced with a 1,000-L (265-gal) double-walled AST. During repairs to a gauge on the tank in 1998, approximately $3.8 \mathrm{~L}(1 \mathrm{gal})$ of diesel fuel were inadvertently released to the ground surface and a small quantity of soil was excavated to remove the released diesel fuel. At this time, an area of dark-brown soil with a petroleum odor was encountered that appeared to be the result of a previous undocumented release or releases of petroleum product at the site. Soil was excavated on both the north and south sides of the AST on February 18, 1998. The two excavated plots at the former location of the AST each measure approximately 1.2 by 0.6 by 0.5 meters $(\mathrm{m})$ ( 4 by 2 by 1.5 feet $[\mathrm{ft}])$. Approximately 0.76 cubic meters $\left(\mathrm{m}^{3}\right)\left(1\right.$ cubic yards [yd $\left.\left.{ }^{3}\right]\right)$ of soil was removed from the two excavations during cleanup of the gauge leak. The excavated soil is still on-site and was placed on plastic and covered.

Once it was determined that the impacted soil uncovered by the excavations was from an older release, digging was stopped and the excavations were covered. A Spill Notification was filed with the NDEM, \#980326-2728 (Appendix A-3). The AST was moved to the East side of Building 24-50 after the discovery of the larger area of impacted soil.

Interviews of site personnel indicated that the original 3,785-L (1,000-gal) AST had several small overfill spills over the 36 years that the ASTs were in place (CAU 499 Project Files, International Technology Corp. [IT], 1999). Soil staining was noted in the area of the excavations as well as in the non-excavated center portion of the former AST staging area as stated in Field Activity Daily Log dated March 3, 1998 (IT, 1999).

The release was from a known source of petroleum hydrocarbons stored in the two ASTs. Process knowledge is adequate to identify the constituent of potential concern (COPC) at this site as diesel fuel. The release mechanism is expected to be numerous small spills over the 36-year lifetime of both tanks. The AST was not located on a cement pad but was set over gravel covered soil. While the volume of the releases is not known, the assumption for the Conceptual Site Model (CSM) is that 10 percent of the 3,785-L (1,000-gal) AST volume was released over the lifetime of the AST. Based on the dimensions of the area within the barricades 3.3 by $3 \mathrm{~m}$ ( 12 by $10 \mathrm{ft}$ ) and an estimated depth to bedrock of $1.5 \mathrm{~m}(5 \mathrm{ft})$, it is estimated that as much as $17 \mathrm{~m}^{3}\left(22 \mathrm{yd}^{3}\right)$ of impacted soil could be present. The actual volume can not be determined until the lateral and vertical extent of the impacted soil is defined (Appendix A-1).

Light bulk petroleum hydrocarbons will migrate downward in an unsaturated soil due to gravity 


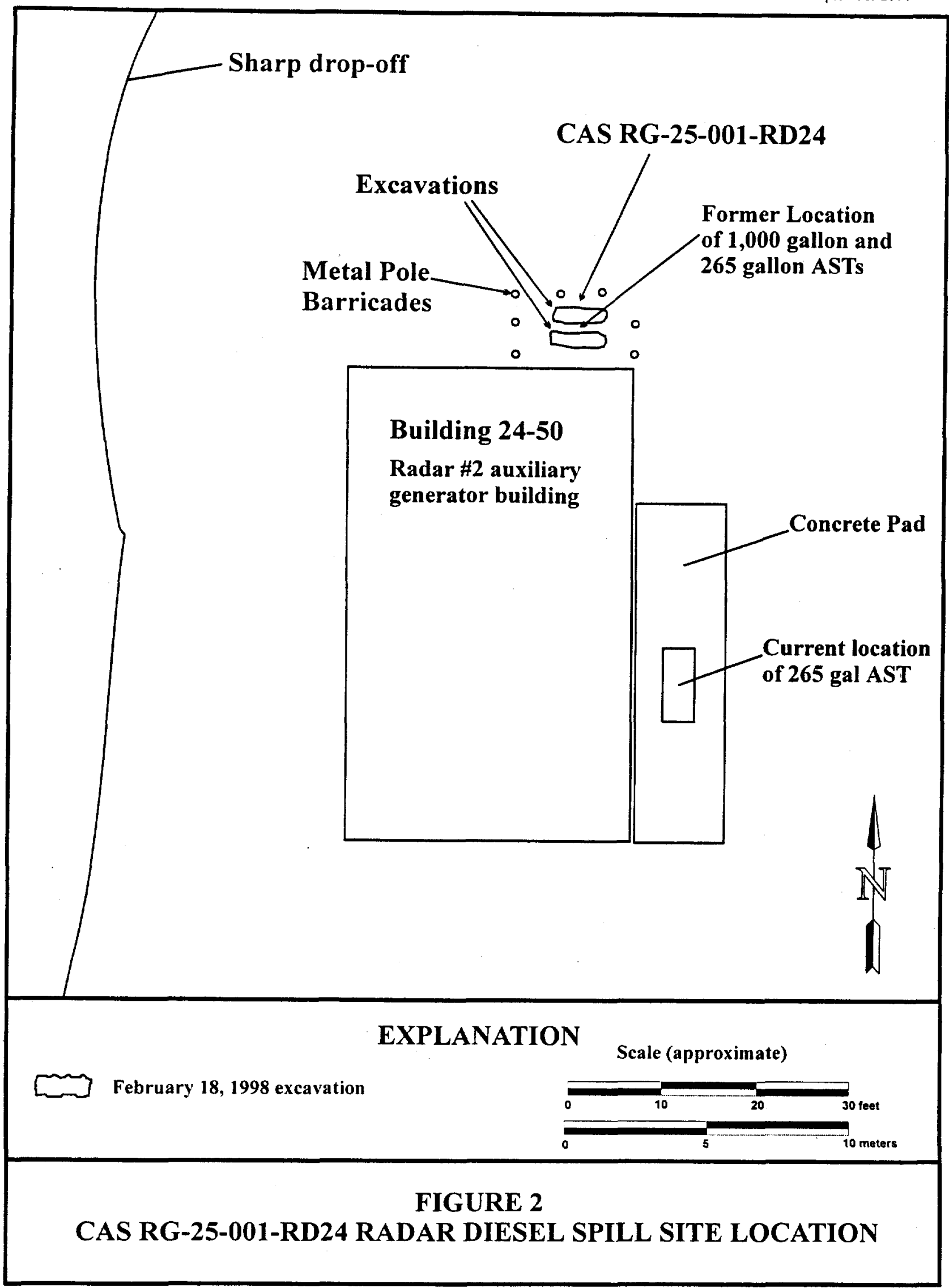


and capillary action. The downward movement will cease when the release reaches either a saturated soil layer or encounters an impermeable boundary. The water table in Cactus Flat is estimated at 110 to $120 \mathrm{~m}$ (361 to $394 \mathrm{ft}$ ) below ground surface (bgs) (U.S. Department of Energy, Nevada Operations Office [DOE/NV], 1996b). The AST was situated on a hill $137 \mathrm{~m}$ $(450 \mathrm{ft})$ above the valley floor and was constructed on fine-grained fill. The groundwater is approximately $300 \mathrm{~m}(985 \mathrm{ft})$ below the area of impacted soil at the Radar 24 facility. Based on site observations along the margin of the Radar 24 facility, the site surface has been raised approximately $1.5 \mathrm{~m}(5[\mathrm{ft}])$ above the existing bedrock surface with a fine-grained fill material. Basaltic bedrock is expected to be present at a depth of approximately $1.5 \mathrm{~m}(5 \mathrm{ft})$ below ground surface. It is estimated that $379 \mathrm{~L}(100 \mathrm{gal})$ of diesel fuel were released over the lifetime of the tanks. Additional information on this assumption is presented in Appendix A-1.

Two samples from the area of the impacted soils were collected for laboratory analysis by Westinghouse personnel. The laboratory results indicated the presence of TPH as diesel range organics up to 7,130 milligrams per kilogram $(\mathrm{mg} / \mathrm{kg})$, and $\mathrm{TPH}$ as gasoline range organics up to $202 \mathrm{mg} / \mathrm{kg}$ (Table 1 and Appendix A-3). Based on process knowledge and the carbon chain overlap between the TPH-gasoline fraction and TPH-diesel fraction, all TPH contamination is associated with diesel fuel. Carbon chain overlap between gasoline and diesel commonly appears with high concentrations of diesel.

\section{TABLE 1 - SAMPLE ANALYTICAL RESULTS FROM} CAS RG-25-001-RD24

\begin{tabular}{||c|c|c|c||}
\hline $\begin{array}{c}\text { SAMPLE } \\
\text { IDENTIFICATION }\end{array}$ & $\begin{array}{c}\text { SAMPLE } \\
\text { LOCATION }\end{array}$ & $\begin{array}{c}\text { SAMPLE DEPTH } \\
\text { BELOW GROUND } \\
\text { SURFACE } \\
\text { (feet) }\end{array}$ & $\begin{array}{c}\text { TOTAL } \\
\text { PETROLEUM } \\
\text { HYDROCARBONS } \\
\text { (mg/kg) }\end{array}$ \\
\hline \hline 11 & $\begin{array}{c}\text { Bottom of } \\
\text { excavation }\end{array}$ & $\begin{array}{c}\text { Sample from } \\
\text { excavated soil up to } \\
1.5 \mathrm{ft}\end{array}$ & $\begin{array}{c}5.1 \text { (gasoline) } \\
\mathbf{4 8 3} \text { (diesel) }\end{array}$ \\
\hline 12 & $\begin{array}{c}\text { Bottom of } \\
\text { excavation }\end{array}$ & $\begin{array}{c}\text { Sample from } \\
\text { excavated soil up to } \\
1.5 \mathrm{ft}\end{array}$ & $\begin{array}{c}202 \text { (gasoline) } \\
7,130 \text { (diesel) }\end{array}$ \\
\hline
\end{tabular}

'TPH analysis by Method 8015B, U.S. Environmental Protection Agency's (EPA's) Test Methods for Evaluating Solid Waste, $3^{\text {rd }}$ Edition, Parts 1-4, SW-846 (EPA, 1996)

\subsection{SITE LOCATION AND DESCRIPTION}

\subsubsection{CAS RG-25-001-RD24: Radar 24 Diesel Spill Site (NDEM \#980326-2728)}

CAS RG-25-001-RD24 consists of the area of impacted soil associated with the series of hydrocarbon releases over the 36-year lifetime of the two ASTs. CAS RG-25-001-RD24 is located on the north side of Building 24-50 on the TTR. The ASTs were set over a foundation of fill soil and surrounded by bumper posts. There was no spill protection or secondary containment associated with the original AST. Any spills or leaks landed directly on the gravel bedding placed to support the Radar 24 facility. The total volume of diesel released at the site is 
unknown. Based on field observations, the Radar 24 site soil pad is estimated to be up to $1.5 \mathrm{~m}$ $(5 \mathrm{ft})$ thick and is underlain by fractured basaltic bedrock.

\subsection{PROCESS KNOWLEDGE}

Information collected during the preliminary site assessment includes interviews of site personnel, review of historical records, and logs of field activities. This information was generated by the IT Industrial Sites Preliminary Assessments group and can be obtained from the IT Las Vegas Office project files (IT, 2000).

\subsubsection{CAS RG-25-001-RD24: Radar 24 Diesel Spill Site (NDEM \#980326-2728)}

Approximately $379 \mathrm{~L}$ ( 100 gal) of diesel is estimated to have been released from the two tanks located on the north side of Building 24-50. The ASTs supplied diesel fuel to an emergency generator located inside the building. Approximately $0.76 \mathrm{~m}^{3}\left(1 \mathrm{yd}^{3}\right)$ of impacted soil was removed during cleanup of the most recent of the $1,000 \mathrm{~L}$ ( $265 \mathrm{gal})$ tank gauge leak. Two samples from the impacted soils indicated a presence of TPH as diesel range organics up to $7,130 \mathrm{mg} / \mathrm{kg}$, and TPH as gasoline range organics up to $202 \mathrm{mg} / \mathrm{kg}$. Analytical results from all of the sampling activities are summarized in Table 1.

Using the CSM (Appendix A-1), an estimated $379 \mathrm{~L}$ (100 gal) of diesel fuel was released at CAS RG-25-001-RD24. The volume of soil required to immobilize this volume of diesel can be calculated. A soil volume of $6 \mathrm{~m}^{3}\left(8 \mathrm{yd}^{3}\right)$ was calculated using the following equation:

$\mathrm{V}_{\mathrm{rs}}=0.2 \mathrm{~V}_{\mathrm{hc}} / \mathrm{P} \times \mathrm{RS}$ (Dragun, 1988)

where:

$\mathrm{V}_{\mathrm{rs}}$ is the cubic yards of soil required for residual saturation

$V_{h c}$ is the volume of hydrocarbon released in barrels ( 2.3 barrels [ 44 gal/barrel])

$P$ is soil porosity (estimated at 0.41 )

$\mathrm{RS}$ is residual saturation capacity of the soil (for light fuel oil $=0.15$ )

A $0.6-\mathrm{m}(2-\mathrm{ft})$ depth of infiltration was then calculated using th following equations:

$\mathrm{D}=\mathrm{V}_{\mathrm{rs}} / \mathrm{A}$ (Dragun, 1988)

where:

$\mathrm{D}$ is the depth of penetration in yards

$\mathrm{V}_{\mathrm{rs}}$ is the volume of residually saturated soil in cubic yards

$\mathrm{A}$ is the surface area of infiltration in square yards (assumed to be the area within the AST barricades $=13 \mathrm{yd}^{2}$ )

These calculations are based on assumptions made in the CSM (Figure 3). The volume of impacted soil and the depth of penetration could be different if the volume of releases was greater than estimated or the area of the release is smaller than estimated. A worst-case calculation of a $4.6 \mathrm{~m}(15 \mathrm{ft})$ by $4.6 \mathrm{~m}(15 \mathrm{ft})$ by $1.5 \mathrm{~m}(5 \mathrm{ft})$ impacted area results in an estimated volume of $32 \mathrm{~m}^{3}\left(42 \mathrm{yd}^{3}\right)$.

The CSM (Appendix A-1) also assumes that the diesel impacted soil does not extend under the Building 24-50 foundation or to the depth of bedrock (Figure 4). 


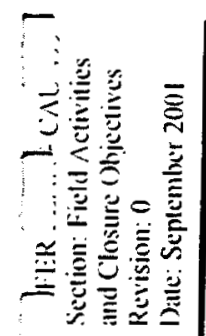

$-$
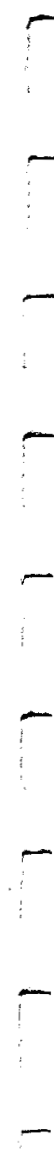

$-$
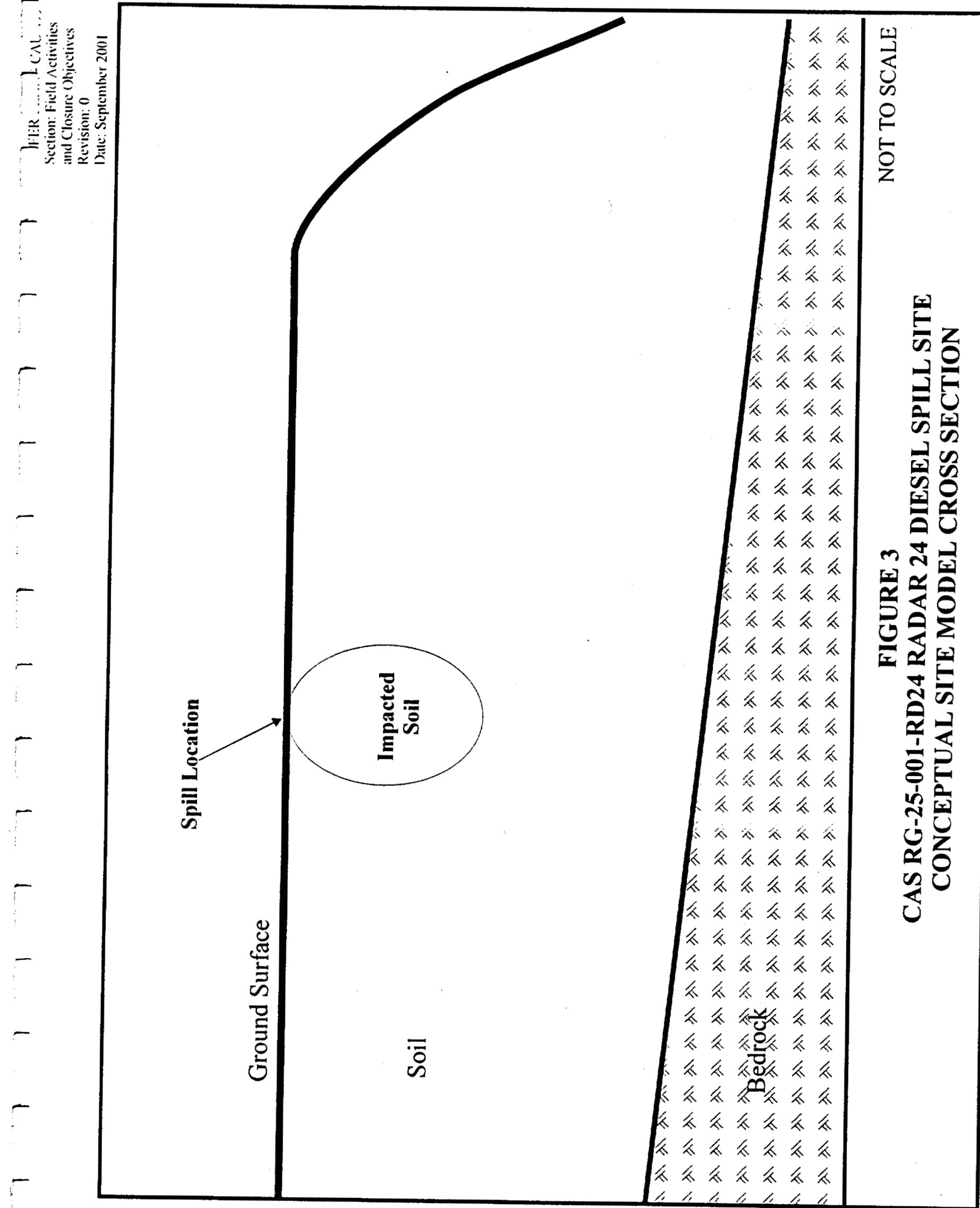


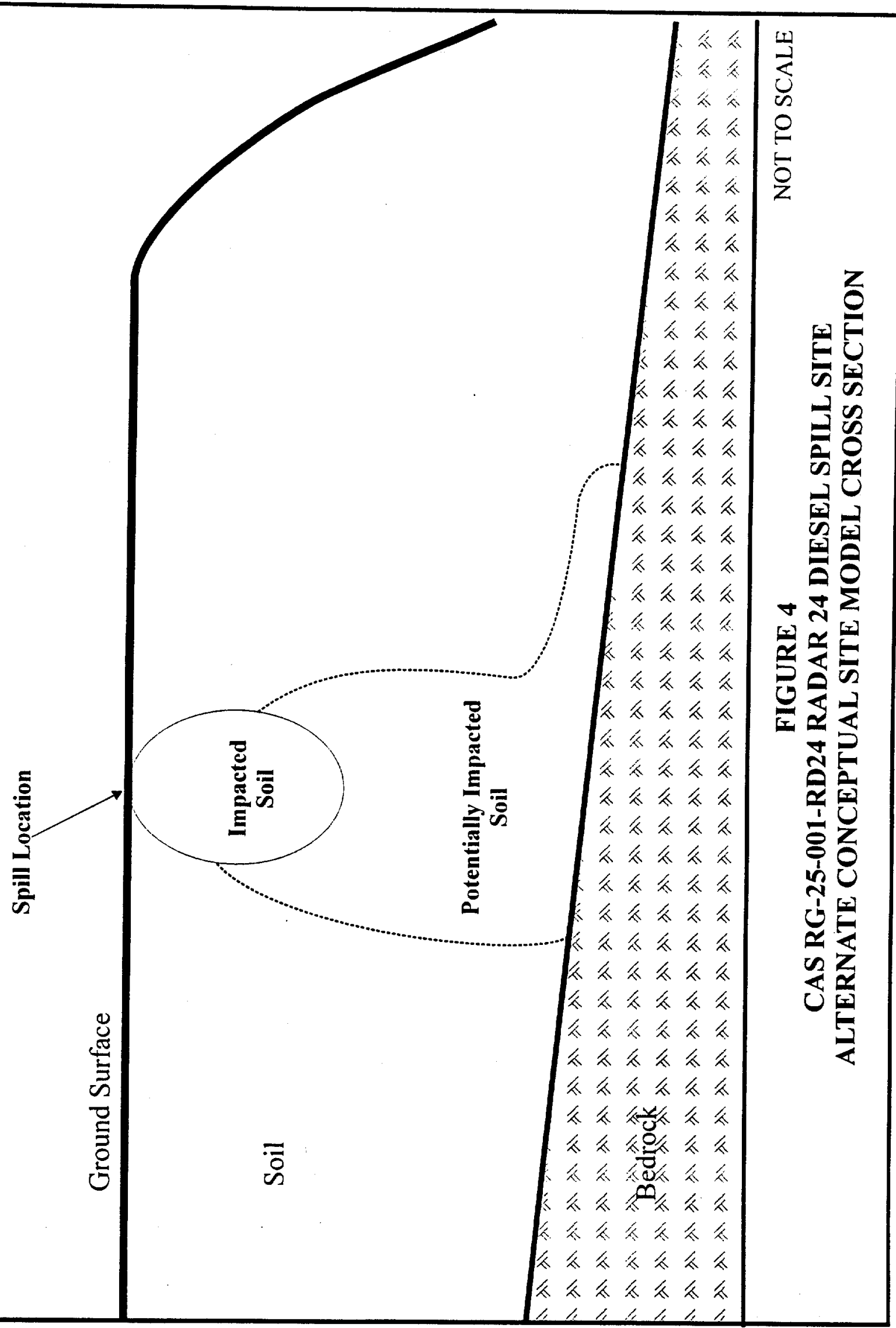




\subsection{CLOSURE STANDARDS}

The clean closure standard for the purpose of closure verification for this SAFER Plan is a $\mathrm{TPH}$ concentration less than the $100 \mathrm{mg} / \mathrm{kg}$ ( NAC, 2000). 
$-$

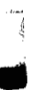




\subsection{FIELD ACTIVITIES AND CLOSURE OBJECTIVES}

This section provides the framework and rationale for characterization, removal, closure verification, site restoration, and waste disposal. The SAFER process is discussed in detail in the following subsections.

Before field activities begin, the following activities will be completed:

- Conduct an endangered species survey.

- Preparation of a National Environmental Policy Act permit.

- Preparation of a Site-Specific Health and Safety Plan.

- Cultural Resource Survey. Because of the potential to harm cultural resources, off-road driving in areas surrounding the sites is not allowed.

- Preparation of a Real Estate Operations Permit.

\subsection{CONSTITUENTS OF POTENTIAL CONCERN}

\subsubsection{CAS RG-25-001-RD24: Radar 24 Diesel Spill Site}

The process knowledge for CAU 499 is that only diesel fuel was stored in the ASTs located at the Radar 24 site. Based on this and the results of the samples collected from the excavated soil by Westinghouse personnel (Table 1 and Appendix A-3), TPH is the only COPC.

\subsection{REMEDIATION}

Remedial activities associated with the closure of CAU 499 are given below.

\subsubsection{CAS RG-25-001-RD24: Radar 24 Diesel Spill Site}

CAS RG-25-001-RD24 will be closed by taking the following actions:

- $\quad$ Locating the Horizontal Extent of Petroleum Hydrocarbon-Impacted Soil: The horizontal extent of impacted soil will be determined by using either a Geoprobe direct push soil sampler or backhoe to collect samples radiating outward from the two earlier sampling excavations. Step-out sampling locations will be placed at $1-\mathrm{m}(3-\mathrm{ft})$ intervals on four sides of the original spill sample location. Samples collected from these step-out locations will be screened in the field using a TPH screening kit (PetroFLAG or equivalent). The lateral step out will continue in each direction until the TPH screening kits report a TPH content of less than $75 \mathrm{mg} / \mathrm{kg}$.

- $\quad$ Locating the Vertical Extent of Petroleum Hydrocarbon Impacted-Soil: The vertical extent of impacted soil will be determined by using either a Geoprobe direct push soil sampler or backhoe. Samples will be collected at $0.3-\mathrm{m}(1-\mathrm{ft})$ intervals from each horizontal sampling location. Vertical samples will be collected until either the TPH 
screening kits (PetroFlag or equivalent) report a TPH content of less than $75 \mathrm{mg} / \mathrm{kg}$ or bedrock is reached.

- Excavate Impacted Soil above $100 \mathrm{mg} / \mathrm{kg}$ : The volume of soil determined to be impacted during the vertical and horizontal characterization activities will be excavated and stockpiled on plastic adjacent to the excavation area. After the estimated volume of soil has been excavated, a number of verification samples will be collected and screened for TPH (PetroFlag or equivalent) to determine if all of the TPH impacted soil has been removed from the site. If all of the TPH screening samples contain less than $75 \mathrm{mg} / \mathrm{kg}$ $\mathrm{TPH}$, then excavation activities are completed. If a sample exceeds the $75 \mathrm{mg} / \mathrm{kg} \mathrm{TPH}$ level, additional soil will be excavated from that specific area. This will continue until all samples meet the release criteria or bedrock and/or Building 24-50 foundation is encountered.

- Verification Soil Sample Collection: Once all visibly stained soil and all soil with TPH screening results greater than 75 parts per million (ppm) have been removed, soil verification samples will be collected from the excavation. Soil verification samples will be collected from each sidewall, and the bottom of the excavation. A minimum of three samples will be collected from each sidewall, and a minium of five samples from the bottom of the excavation. On each sidewall the samples locations will be in a triangular pattern, with two samples collected within $0.3 \mathrm{~m}(1 \mathrm{ft})$ of the base of the sidewall, and the remaining sample collected from the upper portion of the sidewall. The anticipated size of the excavation is 3.6 by 3 by $1.5 \mathrm{~m}$ ( 12 by 10 by $5 \mathrm{ft}$ ). If the excavation exceeds these dimensions, the number of verification samples collected will increase to confirm that clean-up criteria have been met for the entire excavation. Additional samples may be required if the first set of verification samples indicate that COCs are still present. Each sample will be submitted for laboratory analysis of TPH full scan by EPA Method 8015, modified (EPA, 1996).

- Disposal of TPH Impacted Soil: Upon completion of excavation activities, TPH impacted soil will be loaded onto trucks for transport to the NTS Area 6 Petroleum Hydrocarbon Landfill. A waste management professional will be on-site and will generate all required shipping paperwork/shipping manifests.

- Backfilling Excavation with Clean Fill: Clean fill will be excavated from the nearest TTR borrow pit and transported to the CAU 499 site. The excavation will be backfilled using a front-end loader or equivalent equipment. Material placed into the excavation will be compacted by wheel rolling over the excavation. If necessary, water will be sprayed onto the fill material during the backfill activity to reduce dust and promote compaction.

- A through K Evaluation: If the TPH impacted soil extends under the Building 24-50 foundation or extended to bedrock, the site will be evaluated using the "A through $\mathrm{K}$ " criteria (NAC, 2000) and, as warranted, administrative closure of the CAS will be requested.

Survey for Use Restriction: If an "A through K" evaluation is conducted, a survey of at least four points that will bound the area impacted with TPH will be conducted. A Use Restriction will be requested in the CR. 


\subsection{VERIFICATION}

In order to assess the completeness of the remediation activities, biased soil samples will be collected to confirm that all materials exceeding the established clean-up criteria have been removed. Soil verification samples will be collected from each sidewall and the bottom of the excavation. A minimum of three samples will be collected from each side wall and a minimum of five samples from the bottom of the excavation. The anticipated size of the excavation is 3.6 by 3 by $1.5 \mathrm{~m}$ ( 12 by 10 by $5 \mathrm{ft}$ ). If the excavation exceeds these dimensions, the number of verification samples collected will increase to confirm that clean-up criteria have been met for the entire excavation. Additional samples may be required if the first set of verification samples indicate that TPH impacted soil is still present at levels greater than $100 \mathrm{mg} / \mathrm{kg}$. The Bechtel Nevada (BN) soil sampling instruction OI-2152.108 will be followed to collect all soil verification samples (BN, 2000). All samples will be labeled, sample jars sealed with custody tape, placed in individual zip-lock bags, and placed on ice in a cooler for transport to the BN Sample Management group for shipment to an off-site laboratory for analysis. Samples will be identified as "CAU499-V01," etc. Each sample will submitted for laboratory analysis of TPH full scan by EPA Method 8015, modified (EPA, 1996). Table 2 provides the sampling requirements for the verification samples.

\subsection{DATA QUALITY OBJECTIVES}

The DQOs are qualitative and quantitative statements that specify the quality of the data required to support potential closure alternatives for CAU 499. The DQOs were developed to clearly define the purposes for which environmental data will be used and to design a data collection program that will satisfy these purposes. The formulation of a CSM is an aid to the development of DQOs for the site.

Details of the DQO process are presented in Appendix A-1. During the DQO discussions for CAU 499, the information or data needed to resolve problem statements and decision statements were identified. Criteria for data collection and analysis were defined and agreed upon, and the appropriate quality assurance $(\mathrm{QA})$ /quality control $(\mathrm{QC})$ required for particular data collection activities were assigned. The analytical methods and reporting limits prescribed through the DQO process, and the data quality indicators (DQIs) for laboratory analysis, such as a precision and accuracy requirements, are provided in more detail in Section 6.0 of this SAFER Plan. At the end of the investigation, resulting laboratory data will be evaluated to confirm or refute the CSM and determine if the DQOs were met by using the DQIs of precision, accuracy, representativeness, completeness, and comparability. Other DQIs may be used, such as sensitivity.

\subsection{CLOSURE}

Hold points and conditions that are outside of the assumptions in this report may impact the requirements for closure. The proposed activities for closure of CAU 499 are provided below.

\subsubsection{CAS RG-25-001-RD24: Radar 24 Diesel Spill Site}

- The location and extent of impacted soil with TPH levels greater than $100 \mathrm{mg} / \mathrm{kg}$ has been determined. 
TABLE 2 - VERIFICATION SOIL SAMPLING REQUIREMENTS FOR CAU 499

\begin{tabular}{||l|c|c|c|c|c|c|}
\hline PARAMETER & $\begin{array}{c}\text { SAMPLE } \\
\text { NUMBER }\end{array}$ & METHOD & $\begin{array}{c}\text { METHOD } \\
\text { DETECTION } \\
\text { LIMIT }\end{array}$ & $\begin{array}{c}\text { NUMBER OF } \\
\text { QC SAMPLES }\end{array}$ & $\begin{array}{c}\text { CLOSURE } \\
\text { STANDARD }\end{array}$ & $\begin{array}{c}\text { CONTAINER } \\
\text { TYPE }\end{array}$ \\
\hline \hline CAS RG-25-001-RD24 & 18 & $8015 \mathrm{~B}$ Modified & $10 \mathrm{mg} / \mathrm{kg}^{\mathrm{c}}$ & $\begin{array}{l}2 \text { Blind Replicates } \\
2 \text { MS/MSD } \\
\text { 1 Equip. Rinsate }\end{array}$ & $100 \mathrm{mg} / \mathrm{kg}^{\mathrm{a}}$ & $\begin{array}{l}120 \mathrm{ml} \mathrm{g}^{\mathrm{g}} \mathrm{glass,} \\
\text { zero head space }\end{array}$ \\
\hline $\begin{array}{l}\text { Total Petroleum } \\
\text { Hydrocarbons }\end{array}$ & 18 &
\end{tabular}

a - Quality Control

b - Environmental Protection Agency Test Methods for Evaluating Solid Waste, $3^{\text {rd }}$ Edition, Parts 1-4, SW-846 (EPA, 1996)

c - milligrams per kilogram

d - Matrix Spike/Matrix Spike Duplicate

e- milliliter 
- $\quad$ Impacted soil with TPH levels greater than $100 \mathrm{mg} / \mathrm{kg}$ has been excavated from the site.

- Impacted soil has been loaded and transported to the NTS Area 6 Hydrocarbon Landfill.

- The excavation has been backfilled with clean fill.

- An "A through K" evaluation of the site, has been prepared as necessary.

- The site has been surveyed and a Use Restriction has been implemented, as necessary.

- The CR has been approved by the NDEP.

\subsection{DURATION}

The schedule will require modifications if conditions exist that are outside the assumptions on which the schedule was developed. Flexibility has been placed in the project schedule to account for minor difficulties (weather, equipment breakdowns, personnel availability, TTR operational and security constraints, operation and mobility around Building 24-50, etc.). NNSANV will keep the NDEP apprized of any condition that may impact the project schedule. After submittal of the final SAFER Plan for CAU 499 to NDEP, the following is a tentative schedule of activities (in calender days).

- Day 0 - 60: Preparation for fieldwork will be completed and includes development of a Site-Specific Health \& Safety Plan, work packages, Real Estate/Operations Permit, and other required field planning documents and preparation activities.

- Day 60 - 80: Phase 1 Corrective Action Investigation, which will consist of delineation of vertical and horizontal extent of TPH impacted soil.

- Day 80 - 95: Corrective Action Investigation data evaluation.

- Day 95 - 115: Phase 2 Field Closure Activities, which will consist of excavation of TPH impacted soil, collection of verification samples, waste disposal, and backfilling the excavation.

- Day 115 - 130: Phase 2 closure data evaluation.

- Day 130 - 200: Preparation of the CR.

A proposed schedule is provided in Figure 5. 


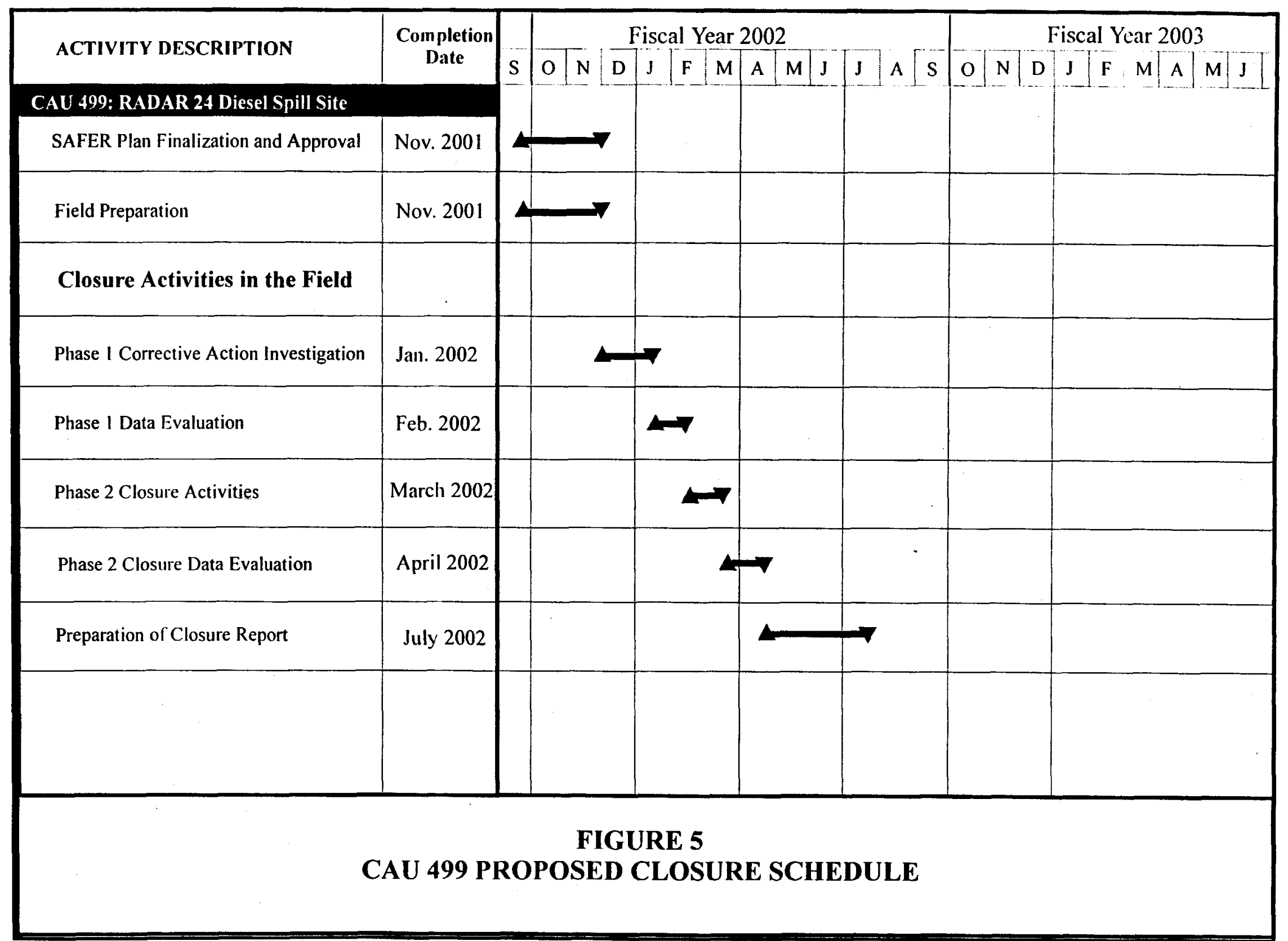

18

a

$\mathbf{L}:$

$\mathbf{O}^{\prime}$

c.

a. .

$A-i$

a.

几

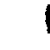




\subsection{REPORTS AND RECORDS AVAILABILITY}

A daily report will be prepared once field activities have started. The report will summarize the daily activities, site visitors, health and safety issues, and any issues or problems and their solutions that may have been experienced. The report will be provided to the NNSANV Task Manager for submittal to the NDEP.

Upon completion of closure activities, a SAFER Closure Report will be prepared in accordance with the NDEP approved document outline, and will include the following:

- Introduction (Purpose and Scope).

- Closure Activities (Description of Corrective Action Activities, Deviation from the SAFER Plan as Approved, Corrective Action Schedule as Completed, and Site Plan/Survey Plan).

- Waste Disposition.

- Closure Verification Results (Data Quality Assessment, Use Restrictions).

- References.

- Supporting Documentation (Analytical Results, As-Built Documentation, Waste Disposition Documentation, Modification to the SAFER Plan).

The final CR will be submitted to NNSA/NV and NDEP for review and approval. This SAFER Work Plan and the subsequent CR will be available in the NNSA/NV Public Reading Rooms located in Las Vegas and Carson City, Nevada, or by contacting the NNSANV Project Manager. The NDEP maintains the official administrative record for all activities conducted under the FFACO (FFACO, 1996). 


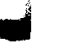

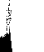

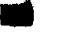

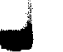

THIS PAGE INTENTIONALLY LEFT BLANK 


\subsection{INVESTIGATION/REMEDIATION WASTE MANAGEMENT}

Wastes from CAU 499 will be managed in accordance with all state and federal regulations, DOE orders, BN procedures, and the Resource Conservation and Recovery Act (RCRA) Operational Permit. Known waste types will include nonhazardous (sanitary/construction debris) waste and hydrocarbon-impacted soils.

\subsection{Waste Minimization}

Waste generation will be minimized by limiting the number of people in the work area. For the duration of the project, site workers will adhere to the principles of the BN Waste Minimization and Pollution Prevention Program. Care will be taken to segregate waste from nonwaste materials, if at all possible, and avoid cross contamination.

\subsection{Potential Waste Streams}

Table 3 shows the waste streams anticipated to be generated during closure of CAU 499 . Table 4 shows the requirements for how these waste types will be managed.

TABLE 3 - POTENTIAL WASTE STREAM AT CAU 499

\begin{tabular}{|c|c|c|c|}
\hline CAS & SANITARY & $\begin{array}{c}\text { HYDROCARBON- } \\
\text { IMPACTED SOIL }\end{array}$ & HAZARDOUS \\
\hline \hline RG-25-001-RD24 & $\mathrm{X}$ & $\mathrm{X}$ & $\mathrm{X}$ \\
\hline
\end{tabular}

\subsubsection{Nonhazardous Waste}

Nonhazardous waste generation (sanitary debris) is expected at CAS RG-25-001-RD24. Nonhazardous waste will consist primarily of used personal protective equipment (PPE), and house keeping debris such as paper and plastic. Where possible this type of debris will be recycled. Non-recyclable materials will be disposed of in the TTR Sanitary Landfill.

\subsubsection{Hydrocarbon-Impacted Soil}

Hydrocarbon-impacted soils are known to exist at CAS RG-25-001-RD24. These soils will be transported and disposed of at the NTS Area 6 Hydrocarbon Landfill.

\subsubsection{Hazardous Waste}

The process of screening soil samples for TPH using the PetroFlag field test kits generates spent methanol as a waste product. Spent methanol is classified by RCRA as a hazardous waste and will be managed as such. The waste will be transported to the NTS and placed in hazardous 
waste Satellite Accumulation Area (SAA) number NTS099 located in Area 23. This SAA is registered and serviced by $\mathrm{BN}$ Waste Operations. The accumulated waste is collected from the SAA at scheduled dates and transported and disposed off-site at an approved, permitted hazardous waste treatment, storage, and disposal facility.

\section{TABLE 4 - MANAGEMENT OF VARIOUS WASTE TYPES TO BE PRODUCED AT CAU 499 CLOSURE}

\begin{tabular}{|l|l|l||}
\hline \multicolumn{1}{|c|}{ MEDIA } & \multicolumn{1}{|c|}{ WASTE TYPE } & WASTE MANAGEMENT \\
\hline $\begin{array}{l}\text { PPE, Sampling Equipment, } \\
\text { and TPH Field Screening } \\
\text { waste. }\end{array}$ & $\begin{array}{l}\text { Material with methanol }> \\
\text { RCRA levels is hazardous } \\
\text { waste. }\end{array}$ & $\begin{array}{l}\text { Material will be transported } \\
\text { to the NTS and placed in } \\
\text { SAA no. NTS099 in Area 23. } \\
\text { It will then be managed in } \\
\text { accordance with NNSANV } \\
\text { and BN procedures governing } \\
\text { hazardous waste. }\end{array}$ \\
\cline { 2 - 4 } & $\begin{array}{l}\text { Material with } \\
\text { TPH < } 100 \text { ppm and } \\
\text { RCRA constiuents }<\mathrm{RCRA} \\
\text { levels is sanitary waste. }\end{array}$ & $\begin{array}{l}\text { Material will be disposed of } \\
\text { in the TTR Sanitary Landfill. }\end{array}$ \\
\hline Soil & Soil with TPH $>100 \mathrm{mg} / \mathrm{kg}$ & $\begin{array}{l}\text { The soil will be transported } \\
\text { to the NTS Area 6 Landfill } \\
\text { for disposal. }\end{array}$ \\
\cline { 2 - 3 } & Soil with TPH $<100 \mathrm{mg} / \mathrm{kg}$ & $\begin{array}{l}\text { The soil will be returned to } \\
\text { the excavation as backfill. }\end{array}$ \\
\hline
\end{tabular}

\subsection{CONTAINER MANAGEMENT}

All containers must be in good condition. If the container begins to leak, the contents must be transferred to a container that is in good condition without dents or significant rust. The containers must always be closed while stored unless waste is being added or removed. They must be handled in such a manner that will not jeopardize the integrity of the container.

Some 208-L (55-gal) drums may be used during this project. Compactable waste will then be placed in 208-L (55-gal) drums. After a container has been filled, the container will be locked. If a container is not completely filled to capacity at the end of a workday, it will be locked and tamper-resistant tape will be placed over the container's hinge. Empty drums will also be locked until needed. Additional precautions include not filling 208-L (55-gal ) drums more than 7/8 full and not mixing waste types (such as PPE and decontamination water).

Because the majority of the waste produced during this project is anticipated to be soil and debris, secondary containment will not be required. If, however, free liquids are placed in containers, such as decontamination water, the containers will be placed on spill containment pallets or within a plastic-lined bermed area. 
Appropriate labels and relevant information will be marked on each container with an indelible marker and must be legible and clearly visible for inspections. Pertinent data shall be written on duct tape or a blank adhesive label that is applied to the side of the container. The following information will be included:

- Waste-Tracking Label.

- Type of waste in the container (i.e., it must be marked "Hazardous Waste" if appropriate).

- Location waste was derived from.

- Date accumulation begins/ends.

- If sampling is required, "Awaiting Analysis" sticker after sampling has been completed. 
THIS PAGE INTENTIONALLY LEFT BLANK

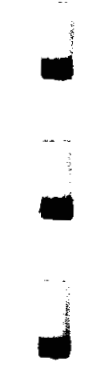




\subsection{QUALITY ASSURANCE/QUALITY CONTROL}

The overall objective of the closure activities described in this plan is to collect accurate and defensible data to support the selection of and to implement a closure alternative for CAU 499. The following sections discuss the collection of required QC samples in the field and QA requirements for laboratory/analytical data to achieve closure.

\subsection{PROPOSED FIELD SAMPLE COLLECTION ACTIVITIES}

Field QC samples will be collected in accordance with established procedures (BN, 2000). Field QC samples are collected and analyzed to aid in determining the validity of sample results. The number of required QC samples depends on the type and number of environmental samples collected. The minimum frequency of collecting and analyzing QC samples for this investigation, as determined in the DQO process, include:

- $\quad$ Equipment blanks (1 per sampling event)

- $\quad$ Blind replicates ( 1 per 20 environmental samples or 1 if less than 20 collected)

- MS/MSD ( 1 per 20 environmental samples or 1 if less than 20 collected)

Additional QC samples may be substituted based on site conditions at the discretion of the Technical Lead (See Table 2). Field QC samples will be analyzed using the same analytical procedures used for environmental samples. The results of the QC sample analysis will be included in the CR.

\subsection{PROPOSED LABORATORY/ANALYTICAL DATA QUALITY INDICATORS}

Criteria for site closure requires laboratory analysis of samples used in decision making to provide a quantitative measurement of any COC present. Rigorous QA/QC will be implemented for all laboratory samples and includes documentation, data verification, validation of analytical results, and meeting the requirements of DQIs as they relate to laboratory analysis.

Data verification and validation will be performed in accordance with established procedures and with this SAFER Plan. All laboratory data from samples collected and analyzed will be evaluated for data quality according to EPA Functional Guidelines (EPA, 1999). The data will be reviewed to ensure that all critical samples were appropriately collected and analyzed, and the results passed data validation criteria. Validated data, whether estimated or not, will be assessed to determine if they meet the DQOs of the investigation and the performance criteria for the DQIs. The results of this assessment will be documented in the CR. If the DQOs were not met, corrective actions will be evaluated, selected, and implemented (e.g., refine CSM or resample to fill data gaps).

DQIs are qualitative and quantitative statements that specify the data requirements of a project and include precision, accuracy, representativeness, completeness, and comparability. In addition, sensitivity has been included as a DQI for laboratory analysis. The performance criteria for each indicator has been selected based on the intended use of the data, current field and 
analytical procedures, and instrumentation. Precision and accuracy goals have been standardized for organic analytes for analytical laboratories under the EPA Contract Laboratory Program (EPA, 1988). Laboratory QC samples used to measure precision and accuracy of analytical procedures will be analyzed using the same analytical procedures used for environmental samples.

Table 5 provides the established performance criteria for each of the DQIs and the impacts to the decision if the criteria are not met. Any deficiencies noted during the investigation that renders the data quality unacceptable will be documented in the CR.

Table 6 provides specific information on the analysis to be performed, acceptable reporting limits, and regulatory limits for verification samples to be collected during closure of CAU 499 .

\subsubsection{Accuracy}

Accuracy is the closeness of a measurement or the mean of a set of results to the true value. Accuracy is a measure of the bias of the measurement system. Indicators for measurement are based on the $(\% \mathrm{R})$ associated with the laboratory analytical control spikes, surrogate spikes, or matrix spikes. Accuracy is then determined by calculation of the $\% \mathrm{R}$ which is the amount recovered divided by the actual amount added times 100 percent.

In addition, there are legal requirements involved in accuracy. Samples must be collected at the correct locations with carefully recorded dates and times. This is done through the use of a chain-of-custody form with custody tape attached to prevent tampering. The chain-of-custody form follows the samples to the contract laboratory to prove that samples were not tampered with and to show that the required hold times were not exceeded. The temperature inside the ice chest used to ship samples must be maintained at $4^{\circ} \mathrm{C} \pm 2^{\circ} \mathrm{C}$. This is checked before shipment and upon receipt by the contract laboratory.

All samples collected for this project will be properly collected and sent to the contract laboratory as will be described in the SAFER Plan.

\subsubsection{Precision}

Precision is a measurement which represents the repeatability of the analytical system. Indicators for measurement are based on field duplicates, laboratory splits, or laboratory replicate analysis. Precision is usually expressed as the relative percent difference (RPD) or standard deviation. One blind replicate will be collected from each CAS.

\subsubsection{Representativeness}

Representativeness is a qualitative judgement which refers to a sample or group of samples that reflect the characteristics of the media at the sampling point. It also includes how well the sampling point represents the actual parameter variations which are under study.

For CAU 499, professional judgement, process knowledge, and historical knowledge will be used to determine the biased sampling locations. No statistical analysis of sampling locations will be required because the sample locations will be selected from the areas of the greatest potential contamination. 


\section{TABLE 5 - LABORATORY/ANALYTICAL DATA QUALITY INDICATORS}

\begin{tabular}{|c|c|c|}
\hline $\begin{array}{c}\text { DATA } \\
\text { QUALITY } \\
\text { INDICATOR }\end{array}$ & $\begin{array}{c}\text { PERFORMANCE } \\
\text { CRITERIA }\end{array}$ & $\begin{array}{c}\text { IMPACT ON DECISION IF } \\
\text { PERFORMANCE CRITERIA NOT } \\
\text { MET }\end{array}$ \\
\hline Precision & $\begin{array}{l}\text { Variations between duplicates (field } \\
\text { and lab) and original sample should } \\
\text { not exceed analytical method- } \\
\text { specific criteria listed in Table } 6 \text {. }\end{array}$ & $\begin{array}{l}\text { Estimated data within samples delivery group } \\
\text { (SDG) will be evaluated for its usability. If data } \\
\text { are determined to not be usable, then data will not } \\
\text { be used in decision and completeness criteria will } \\
\text { not be met. }\end{array}$ \\
\hline Accuracy & $\begin{array}{l}\text { Laboratory control sample results } \\
\text { and matrix spike results should be } \\
\text { within analytical method-specific } \\
\text { criteria listed in Table } 6\end{array}$ & $\begin{array}{l}\text { Estimated data within SDG will be evaluated for } \\
\text { its usability. If estimated data are biased high or } \\
\text { conservative, the data may be used in decision. If } \\
\text { estimated data are biased low and below the } \\
\text { decision threshold, the data may not be used in } \\
\text { decision and completeness criteria may not be met. }\end{array}$ \\
\hline Sensitivity & $\begin{array}{l}\text { Detection limits of laboratory } \\
\text { instruments must be less than action } \\
\text { level for COC. }\end{array}$ & $\begin{array}{l}\text { Cannot determine if } \mathrm{COC} \text { are present at levels of } \\
\text { concern, thereby investigation objectives cannot } \\
\text { be met. }\end{array}$ \\
\hline Completeness & $\begin{array}{l}100 \% \text { of samples submitted to } \\
\text { laboratory } \\
100 \% \text { of requested analyses } \\
\text { performed } \\
100 \% \text { of critical analytes to be valid } \\
80 \% \text { of noncritical analytes to be } \\
\text { valid }\end{array}$ & $\begin{array}{l}\text { 1. Decision of whether or not extent of } \\
\text { contamination has been bounded cannot be } \\
\text { determined. Impacts to completeness will be } \\
\text { assessed. } \\
\text { 2. Decision of whether or not COC (TPH) above } \\
\text { NAC level remain in soil cannot be determined. } \\
\text { Impacts to completeness will be assessed. }\end{array}$ \\
\hline Comparability & $\begin{array}{l}\text { Equivalent samples analyzed using } \\
\text { same analytical methods, the same } \\
\text { units of measurement and detection } \\
\text { limits must be used for like analyses. }\end{array}$ & Inability to use data collected. \\
\hline Representativeness & $\begin{array}{l}\text { Correct analytical method performed } \\
\text { for appropriate COC: valid data } \\
\text { reflects appropriate target } \\
\text { population. }\end{array}$ & $\begin{array}{l}\text { Cannot identify COC or estimate concentration of } \\
\text { COC; therefore, cannot make decision(s) on target } \\
\text { population. }\end{array}$ \\
\hline
\end{tabular}

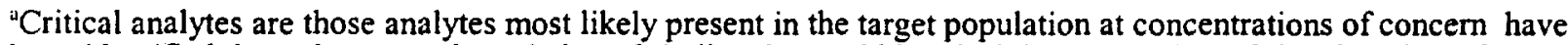
been identified through process knowledge of similar sites and historical documentation. Critical analytes for samples are TPH. 
TABLE 6 - LABORATORY TOTAL PETROLEUM HYDROCARBON PROCEDURE FOR CAU 499

\begin{tabular}{|c|c|c|c|c|c|c|}
\hline $\begin{array}{c}\text { PARAMETER } \\
\text { OR } \\
\text { ANALYTE }\end{array}$ & $\begin{array}{l}\text { MEDIUM OR } \\
\text { MATRIX }\end{array}$ & $\begin{array}{l}\text { ANALYTI } \\
\text { CAL } \\
\text { METHOD }\end{array}$ & $\begin{array}{l}\text { MINIMUM } \\
\text { REPORTING } \\
\text { LIMIT }\end{array}$ & $\begin{array}{l}\text { REGULATORY } \\
\text { LIMIT }\end{array}$ & $\begin{array}{c}\text { RELATIVE } \\
\text { PERCENT } \\
\text { DIFFERENCE } \\
\text { (RPD) } \\
\end{array}$ & $\begin{array}{l}\text { PERCENT } \\
\text { RECOVERY } \\
(\% R)^{b}\end{array}$ \\
\hline \multirow{6}{*}{$\begin{array}{l}\text { Total Petroleum } \\
\text { Hydrocarbons }\end{array}$} & $\begin{array}{l}\text { Water Gasoline } \\
\text { (C8-C12) }\end{array}$ & \multirow{6}{*}{$\begin{array}{l}\text { 8015B } \\
\text { modified }^{\mathrm{c}}\end{array}$} & $0.5 \mathrm{mg} / \mathrm{L}^{\mathrm{d}}$ & $100 \mathrm{mg} / \mathrm{L}^{\mathrm{e}}$ & \multirow{6}{*}{ Lab specific ${ }^{f}$} & \multirow{6}{*}{ Lab specific ${ }^{\prime}$} \\
\hline & $\begin{array}{l}\text { Water Diesel } \\
\text { (C12-C22) }\end{array}$ & & $0.5 \mathrm{mg} / \mathrm{L}^{\mathrm{d}}$ & $100 \mathrm{mg} / \mathrm{L}^{\mathrm{e}}$ & & \\
\hline & $\begin{array}{c}\text { Water Oil } \\
\text { (C22-C34) }\end{array}$ & & $0.5 \mathrm{mg} / \mathrm{L}^{\mathrm{d}}$ & $100 \mathrm{mg} / \mathrm{L}^{\mathrm{c}}$ & & \\
\hline & $\begin{array}{l}\text { Soil Gasoline } \\
\text { (C8-C12) }\end{array}$ & & $10 \mathrm{mg} / \mathrm{L}^{\mathrm{d}}$ & $100 \mathrm{mg} / \mathrm{kg}^{\mathrm{e}}$ & & \\
\hline & $\begin{array}{l}\text { Soil Diesel } \\
\text { (C12-C22) }\end{array}$ & & $10 \mathrm{mg} / \mathrm{kg}^{\mathrm{d}}$ & $100 \mathrm{mg} / \mathrm{kg}^{\mathrm{e}}$ & & \\
\hline & $\begin{array}{c}\text { Soil Oil } \\
\text { (C22-C34) }\end{array}$ & & $10 \mathrm{mg} / \mathrm{kg}^{\mathrm{d}}$ & $100 \mathrm{mg} / \mathrm{kg}^{\mathrm{e}}$ & & \\
\hline
\end{tabular}

'RPD is used to calculate precision. Precision is estimated from the RPD of the concentration measured for the MS/MSD analyses of unspiked field samples, or field duplicates of unspiked samples. It is calculated by:

$R P D=100 \times\left\{\left(\left|C_{1}-C_{2}\right|\right) /\left[\left(C_{1}+C_{2}\right) / 2\right]\right\}$, where $C_{1}=$ concentration of the analyte in the first aliquot, $C_{2}$ is the concentration of the analyte in the second sample aliquot

$\mathrm{b}_{0} \mathrm{R}$ is used to calculate accuracy. Accuracy is assessed from the recovery of analytes spiked into a blank or sample matrix of interest, or from the recovery of surrogate

compounds spiked into each sample. The recovery of each spiked analyte is calculated by: $\% R=100 \times\left(C_{s}-C_{4} / C_{n}\right)$, where $C_{s}=$ concentration of the analyte in the spiked sample, $C_{u}=$ the concentration of the analyte in the unspiked sample, and $C_{n}=$ the concentration increase that should result from spiking the sample.

'EPA's Test Methods for Evaluating Solid Waste, $3^{\text {rd }}$ Edition, Parts 1-4, SW-846 (EPA, 1996)

Industrial Sites Quality Assurance Project Plan (DOE/NV, 1996a)

TPH regulatory limit set in NAC Code, 445A.2272 (NAC,2000).

'In-house generated RPD and \%R Performance Criteria. It is necessary for laboratories to develop in-housc performance criteria and compare them to those in the methods. The laboratory begins by analyzing $15-20$ samples of each matrix and calculating the mean \% $\mathrm{R}$ for each analyte. The standard deviation (SD) of each \% is then calculated, and the warning and control limits for each analyte are established at \pm 2 SD and $+3 \mathrm{SD}$ from the mean, respectively. If the warning limit is exceeded during the analysis of any sample delivery group (SDG), the laboratory institutes corrective action to bring the analytical system back into control. If the control limit is exceeded, the sample results for that SDG are considered unacceptable. These limits are reviewed after every $20-30$ samples of the same matrix and are updated at least semiannually. The laboratory tracks trends in both performance and control limits by the use of control charts. The laboratory's compliance with these requirements is confirmed as part of an annual laboratory audit. Similar procedures are followed in order to generate acceptance criteria for precision measurements.

Definitions:

$\mathrm{mg} / \mathrm{kg}=$ Milligram(s) per kilogram

$\mathrm{mg} / \mathrm{L}=$ Milligram(s) per liter 


\subsubsection{Completeness}

Indicators for this measurement are the amount of valid data obtained from a measurement system compared to the amount that was expected and needed to be obtained to meet the project data goals. Eighty percent of the samples collected for this project will have acceptable Quality Assurance/Quality Control.

\subsubsection{Comparability}

Comparability is a qualitative judgement which expresses the confidence with which one data set can be compared to another. Items used to determine comparability include the analytical method and reporting units. Standardized methods for collection of environmental samples will be used to perform sampling. Samples will be analyzed for TPH full scan using the standard method (8015 modified) (EPA, 1996).

\subsubsection{Data Evaluation}

Laboratory data obtained for CAU 499 will be evaluated for data quality. Data will be evaluated using the following criteria:

- Chain of custody is complete and legible.

- Cover letter (case narrative) is reviewed for significant problems.

- All requested analyses were performed on all samples.

- Holding times are not beyond specified standards.

- Cooler temperature (inside) is not above 6 degrees Celsius.

- $\quad$ Proper preservation and $\mathrm{pH}$ for each matrix was used?

- Check the laboratory log-in report for completeness and errors.

- All field forms are present and complete.

- Report inventory forms includes all Contract Laboratory Protocol (CLP)or CLP-like forms.

- $\quad$ Reporting values are at the appropriate level.

\subsubsection{Quality Control Samples}

One duplicate sample will be collected from each CAS and sent "blind" to the contract laboratory. In addition, one equipment blank for the project will be collected and sent "blind" to the contract laboratory. 


\subsubsection{Laboratory Quality Control Samples}

Each sample delivery group will have a matrix spike/matrix spike duplicate, laboratory control spike/laboratory control spike duplicate, and method blank. A surrogate spike will be added to each sample. These data will be used to qualify the associated sample results. Surrogates check each environmental sample to determine if the extraction and analysis procedure was performed correctly and if the instrumentation is operating as expected. Surrogates are compounds which are highly unlikely to be present in the environment, but have been determined to be similar in behavior to the constituents of concern. The surrogate is added before extraction is started, and the amount recovered is used to calculate $\% \mathrm{R}$. The acceptable range for surrogate recovery is determined by each laboratory. 


\subsection{REFERENCES}

Bechtel Nevada, 2000. Organization Procedure OP-2152.108, "Soil Sampling."

BN, see Bechtel Nevada.

DOE/NV, see U.S. Department of Energy, Nevada Operations Office.

Dragun, J. 1988, The Soil Chemistry of Hazardous Materials. Hazardous Material Control Research Institute, Silver Springs, MA.

EPA, see U.S. Environmental Protection Agency.

FFACO, see Federal Facility Agreement and Consent Order.

Federal Facility Agreement and Consent Order of 1996, as amended. Agreed to by the Nevada Division of Environmental Protection, U.S. Department of Energy, and U.S. Department of Defense.

IT, see International Technology Corporation.

International Technology Corporation. 1999. CAU 499, Hydrocarbon Spill Site, TTR, CAS RG25-001-RD24 Project Files, Las Vegas, NV.

NAC, see Nevada Administrative Code.

Nevada Administrative Code, Section 445A.2272. July 2000.

Occupational Safety and Health Administration. 2001. Title 29 Code of Federal Regulations 1910.120, Hazardous Waste Operations and Emergency Response, Washington, D.C.

OSHA, see Occupational Safety and Health Administration.

U.S. Department of Energy, Nevada Operations Office. 1994. Nevada Environmental Restoration Project. Project Management Plan, Revision 0.

U.S. Department of Energy, Nevada Operations Office. 1996a. Industrial Sites Quality Assurance Project Plan, Nevada Test Site, Nevada, Revision 1, DOE/NV-372.

U.S. Department of Energy, Nevada Operations Office. 1996b. Corrective Action Unit Work Plan. Tonopah Test Range, Nevada, DOE/NV-443.

U.S. Environmental Protection Agency. 1988. Contract Laboratory Program Statement of Work for Organic Analysis, SOW No. 288, EPA/540/R-94/096. Washington, D.C.

U.S. Environmental Protection Agency. 1996. Test Methods for Evaluating Solid Waste Physical/Chemical Methods (SW-846) Third Edition, Washington, D.C.

U.S. Environmental Protection Agency. 1999. Contract Laboratory Program National Functional Guidelines for Organic Data Review, EPA/540/R-99/008. Washington, D.C. 
U.S. Environmental Protection Agency. 2000. Guidance for the Data Quality Objective Process, EPA QA/G-4, EPA/600/R-96-055. Washington, D.C. 


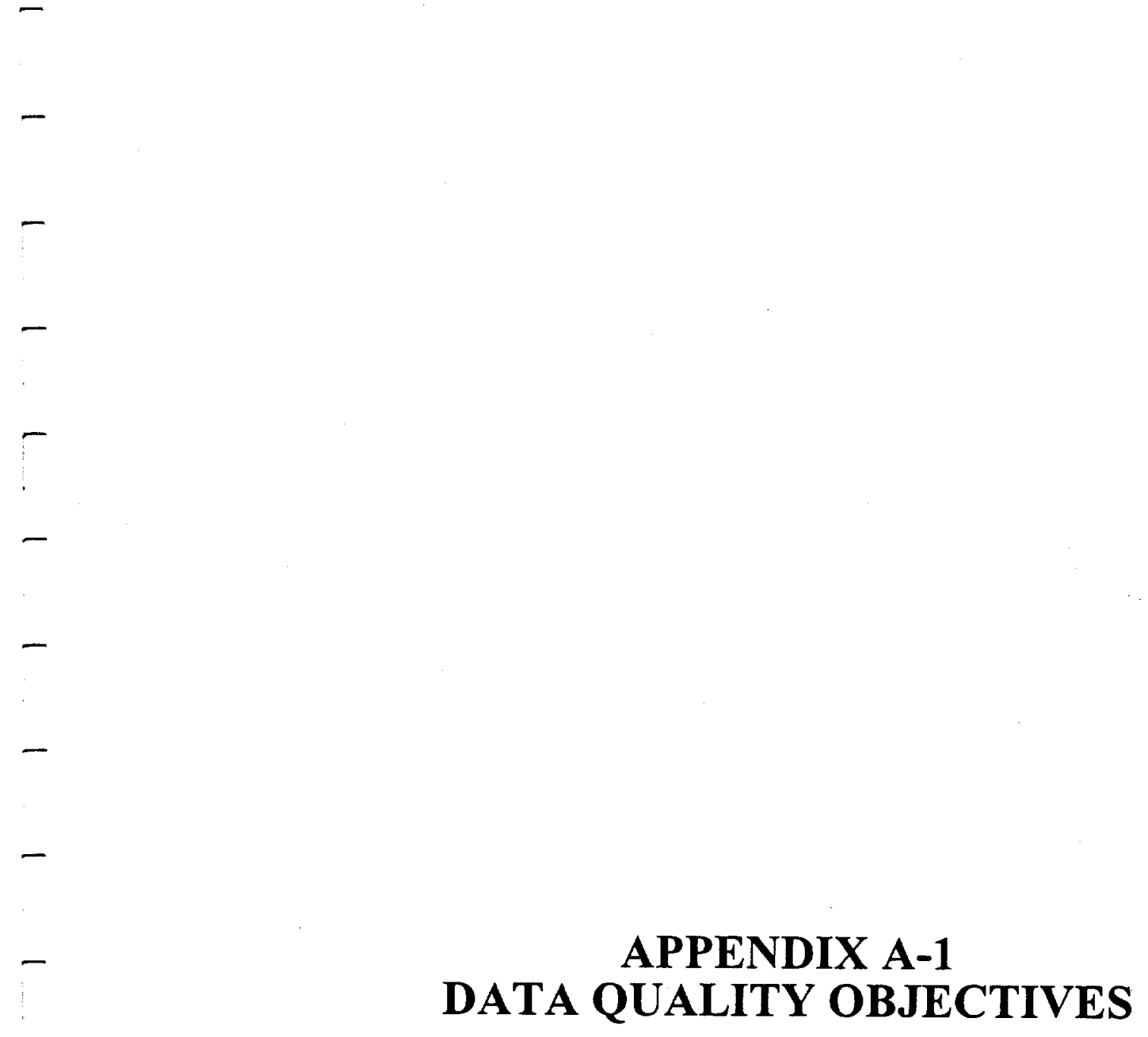




\section{DATA QUALITY OBJECTIVES WORKSHEETS FOR CORRECTIVE ACTION UNIT 499: HYDROCARBON SPILL SITE, TTR}

The information presented in this worksheet is based on historical data generated from preliminary assessment activities for Corrective Action Unit 499 at the Tonopah Test Range. Data quality objective (DQO) worksheets follow the U.S. Environmental Protection Agency (EPA) DQO guidance outline (EPA, 2000). The steps systematically build on the data acquired during preliminary assessment work and background research. Copies of the preliminary assessment work are retained in the project files.

Members of the Scoping Team:

1. U.S. Department of Energy/National Nuclear Safety Administration. Nevada Operations Office (NNSA/NV)

Janet Appenzeller-Wing

Kevin Cabble

2. Bechtel Nevada (BN)

Brad Jackson

Jeff Smith

Dan Tobiason

Kraig Knapp

3. Nevada Division of Environmental Protection (NDEP)

Clem Goewert

4. International Technology Corporation (IT Corp.)

Lynn Kidman

Core Decision Team

Janet Appenzeller-Wing (NNSA/NV)

Kevin Cabble (NNSANNV)

Brad Jackson (BN)

Primary Decision Makers

Janet Appenzeller- Wing (NNSA/NV)

Kevin Cabble (NNSA/NV)

Clem Goewert (NDEP) 


\subsection{PROBLEM STATEMENT}

\subsection{State the problem}

Corrective Action Unit (CAU) 499 located at the Tonopah Test Range (TTR) has been identified for closure. In order to properly close this site, currently available data must be evaluated to determine if the data adequately identifies constituents of potential concern (COPCs). This data will also be utilized to ascertain clean-up levels and verification sampling requirements. CAU 499 is comprised of one Corrective Action Site (CAS): RG-25-001-RD24, Radar 24 Diesel Spill Site.

1.2 Summarize the problem - combine the relevant background information into a concise description of the problem to be resolved and known or suspected sources of disposed waste.

\subsubsection{CAS RG-25-001-RD24, Radar 24 Diesel Spill Site}

This site is located on the TTR on the north side of Building 24-50 at the Radar 24 Site. The Radar 24 Site is approximately 4.0 kilometers (2.5 miles) southwest of the Area 3 compound at the end of Avenue 24. The CAS presently consists of an area of petroleumimpacted soil located adjacent to the north side of Building 24-50 at the TTR. The site was the former location of a 3,785-liter (L) (1,000-gallon [gal]) above ground storage tank (AST) that supplied diesel fuel to an emergency generator at the site from the early 1962 until approximately 1992 . In 1992, the 3,785-L (1,000-gal) AST was replaced with a 1,000-L (265-gal) double-walled AST.

During repairs to a gauge on the tank in 1998, approximately one gal of diesel fuel was inadvertently released to the ground surface and a small quantity of soil was excavated to remove the released diesel fuel. At this time, an area of dark-brown soil with a petroleum odor was encountered that appeared to be the result of a previous undocumented release or releases of petroleum product at the site. Once it was determined that the impacted soil uncovered by the excavations was from an older release, digging was stopped and the excavations were covered. Two soil samples were collected and analyzed for total petroleum hydrocarbons (TPH). The results indicated the presence of TPH as diesel at levels of up to 7,130 milligrams per kilogram $(\mathrm{mg} / \mathrm{kg})$ and TPH as gasoline at levels up to $202 \mathrm{mg} / \mathrm{kg}$. The positive result for gasoline is likely caused by overlap in the hydrocarbon chains between gasoline and diesel. There is no documentation or process knowledge of the site to indicate that gasoline was stored or used at the site. To ensure that further releases of diesel fuel did not occur at the site, the 1,000-L (265-gal) doublewalled AST was relocated to the east side of Building 24-50 and placed on a concrete slab.

It is unknown when or how much fuel was spilled at this site. Documentation and historical information indicate that an AST had been present at this site since 1962 until it was moved in 1998. During that time, it is estimated that several spills have occurred. The lateral and vertical extent of the impacted soil is unknown.

Prior to or during construction of the Radar 24 facility, the top of the hill where the Radar 24 facility is presently located was graded to form a flat surface and fill material was brought to the site to form a foundation. Based on site observations along the margin of the Radar 24 facility, the site surface has been raised approximately 1.5 meters (m) 
5 feet ( $\mathrm{ft}$ )above the existing bedrock surface with a fine-grained fill material. Basaltic bedrock is expected to be present at a depth of approximately $1.5 \mathrm{~m}(5 \mathrm{ft})$ below ground surface.

\subsection{DEVELOP/REFINE THE CONCEPTUAL MODEL}

\subsection{Primary Model for CAS RG-25-001-RD24, Radar 24 Diesel Spill Site}

The primary model is considered the most probable scenario for current conditions at the Radar 24 Site. Available information from which the conceptual model is based was derived from site process knowledge, historical background information, and personnel interviews relative to the design operations and history of the Radar 24 Site AST.

The proposed activities are based upon the assumption that the contaminants at the site are restricted to petroleum hydrocarbons from a known source which have been released in small quantities from 1962 until 1998. The model also assumes the pathway for the release was to surface soil with no preferential pathways. Both the 3,785-L (1,000-gal) AST and the 1,000-L (265-gal) AST were not located on a cement pad but were set over gravel-covered soil within a 10 by 12 -ft barricaded area. Infiltration is assumed to be limited to the soil underlying this barricaded area and is at residual saturation with no free product in contact with the underlying bedrock. While the volume of the historical releases is not known, the assumption for the conceptual model is that 10 percent of the $3,785-\mathrm{L}(1,000$-gal) tank volume has been released since operations began in $1962(10 \%$ of $3,785-\mathrm{L}(1,000$-gal) equals $400 \mathrm{~L}$ or $100 \mathrm{gal})$.

Light bulk hydrocarbon (No. 2 Diesel) will migrate downward in unsaturated soil due to gravity and capillary action. The downward movement will cease when the release reaches either residual saturation or encounters an impermeable boundary. The primary conceptual model assumes that the fine-grained fill material is homogeneous from the ground surface to bedrock, approximately $5 \mathrm{ft}$.

The water table in that part of the TTR (Cactus Flat) is estimated at 110 to $120 \mathrm{~m}$ ( 361 to $394 \mathrm{ft}$ ) below ground surface. The AST was situated on a hill $137 \mathrm{~m}(450 \mathrm{ft})$ above the valley floor and was constructed on fine-grained fill estimated to be approximately $1.5 \mathrm{~m}$ $(5 \mathrm{ft})$ thick and underlain by basaltic bedrock. The groundwater table is approximately $300 \mathrm{~m}(1,000 \mathrm{ft})$ below the area of petroleum-impacted soil at the Radar 24 facility. Groundwater impact is not considered probable and is not being considered in this investigation.

A non-rigorous calculation can be made to estimate the depth and extent of a given release. For typical sandy soils and assuming a 400-L (100-gal) release over an area of 3.3 by $4 \mathrm{~m}$ ( 10 by $12 \mathrm{ft}$ ), the volume of soil required to immobilize a given amount of hydrocarbon can be grossly estimated (Dragun, 1988) by:

$$
\mathrm{V}_{\mathrm{rs}}=0.2 \mathrm{~V}_{\mathrm{hc}} / \mathrm{P} * \mathrm{RS}
$$

Where: $\quad V_{r s} \quad$ is cubic yards of soil required for residual saturation

$\mathrm{V}_{\mathrm{hc}}$ is volume of hydrocarbon release (in barrels [44 gal/barrel])

$\mathrm{P}$ is soil porosity (estimated at 0.4 )

RS is residual saturation capacity of the soils (for light fuel oil $=0.15$ ) 


$$
V_{\mathrm{rs}}=8 \mathbf{y d}^{3}
$$

The depth of infiltration can be grossly estimated by

$$
\mathrm{D}=\mathrm{V}_{\mathrm{rs}} / \mathbf{A}
$$

Where: $\quad \mathrm{D}$ is depth of penetration in yards

$\mathrm{V}_{\mathrm{rs}} \quad$ is volume of residually saturated soil

$A$ is surface area of infiltration in $\mathrm{yd}^{2}$

$\mathrm{D}=0.6$ yards ( 2 feet)

For a 400-L (100-gal) spill, the estimated volume of soils at residual saturation is approximately 6 cubic meters $\left(\mathrm{m}^{3}\right)\left(8\right.$ cubic yards $\left.\left[\mathrm{yd}^{3}\right]\right)$ with a depth of infiltration of

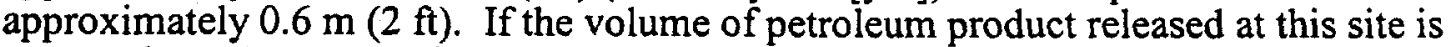
greater than 10 percent of the volume of the tank, the volume of petroleum-impacted soil and depth of infiltration will be significantly higher. The conceptual model for the release can reasonably be constrained to occur as residual saturation hosted within the subsurface soils in the immediate vicinity of the tank or along the soil/bedrock boundary.

\section{$2.2 \quad$ Alternate Model}

The conditions under the alternate model are considered less likely than conditions outlined in the primary model.

The alternate conceptual site model for CAS RG-24-001-RD24 is similar to the primary model with the following exceptions:

- The volume of petroleum released to the environment exceeds 10 percent of the tank volume and has resulted in increased vertical and horizontal migration.

- Infiltration of petroleum product has extended past the $1.5-\mathrm{m}(5-\mathrm{ft})$ depth of finegrained fill material and has made significant contact with the underlying bedrock. Vertical migration within the basaltic bedrock is dominantly along preferential pathways such as joints and fractures.

- The volume of petroleum-impacted soil exceeds the primary conceptual model volume of $6 \mathrm{~m}^{3}\left(8 \mathrm{yd}^{3}\right)$.

3.0 IDENTIFY THE DECISION (Select the appropriate decision for the current phase of the site assessment process)

Development of a SAFER Plan can begin based on the currently available process knowledge, historical data, and sampling data. The primary decisions to be made for the investigation and remediation of the Radar 24 site, CAS RG-25-001-RD24 are: should the site be clean closed, closed in place after conducting some remediation activities, or closed in place with administrative controls? 
3.1 If only the soil is impacted with petroleum hydrocarbons then the site can be clean closed by excavation of the petroleum-impacted soil.

3.2 If the bedrock is impacted with petroleum hydrocarbons, then the site can be closed in place after conducting some remediation activities. The remedial activities will include excavation and disposal of the petroleum-impacted soil while leaving the impacted bedrock in place. Evaluate sampling results against the "A through K" criteria to identify if the implementation of a Use Restriction after excavating impacted soil will adequately protect human health and the environment.

3.3 If the bedrock is impacted with petroleum hydrocarbons, then the site can be closed in place with administrative controls. Evaluate sampling results against the "A through K" criteria to identify if the implementation of a Use Restriction with no other actions will adequately protect human health and the environment.

\subsection{IDENTIFY THE INPUTS TO THE DECISION}

\subsection{Identify the information inputs needed and resolve the decision for the Radar 24} site, CAS RG-25-001-RD24.

a. What is the definition of petroleum-impacted soil for this site? Petroleum-impacted soil will be any soils that have a TPH concentration of 100 milligrams per kilogram $(\mathrm{mg} / \mathrm{kg})$ or higher.

b. What is the lateral and vertical extent of petroleum-impacted soil?

Collect samples using the Geoprobe to determine the lateral and vertical extent of impacted soil. Screen the soil samples collected for the presence of TPH. Confirmation samples will be collected for laboratory analysis when TPH screening results are below 75 parts per million $(\mathrm{ppm})$ or when bedrock is reached. The site will be considered clean when all confirmatory samples are less than $100 \mathrm{mg} / \mathrm{kg}$.

c. What is the depth to bedrock and have petroleum hydrocarbons impacted the bedrock?

The Geoprobe and/or backhoe will be used to determine the vertical depth of petroleum-impacted soil and/or the depth to bedrock. Excavation of impacted soil to the base of the zone of petroleum impact and/or to the bedrock surface will also determine if the bedrock has been impacted.

d. Should the site be clean closed, closed in place after conducting some remediation activities, or closed in place with administrative controls?

The closure option chosen for the Radar 24 site, CAS RG-25-001-RD24 will be dependent upon the extent of petroleum impact in the subsurface and the depth to bedrock.

\subsection{List types of COPCs and affected media}

Previous sampling and laboratory analysis of soil from this site have confirmed that TPH is the only contaminant of concern at the Radar 24 site, CAS RG-25-001-RD24.

Process knowledge and existing documentation confirm that diesel fuel was the only 
petroleum product used at this site.

\subsection{Identify potential sampling approaches and appropriate analytical methods}

a. Verify the presence of TPH greater than the action level: Collect samples from the spill area and field test using a PetroFLAG ${ }^{\mathrm{TM}}$ (or equivalent) test kit. Collect biased samples from the areas of greatest TPH concentration and submit for laboratory analysis for TPH (full scan) using U. S. Environmental Protection Agency (EPA) Method 8015 Modified. These samples will be used to confirm the presence and concentration of TPH in the soil at the site and for waste identification and characterization purposes.

b. Identify the lateral and vertical extent of TPH exceeding the action level: Collect samples using the Geoprobe from the spill area and analyze using a PetroFLAG ${ }^{\mathrm{TM}}$ (or equivalent) test kit. Collect samples at $0.3-\mathrm{m}(1-\mathrm{ft})$ intervals until bedrock is reached or until field screening results indicate less than $75 \mathrm{ppm} \mathrm{TPH.}$

Collect samples from step-out locations using the Geoprobe and analyze using a PetroFLAG ${ }^{\mathrm{TM}}$ (or equivalent) test kit. Step-out samples will be collected at $1-\mathrm{m}$ (3-ft) intervals and will be analyzed vertically at $0.3-\mathrm{m}(1-\mathrm{ft})$ intervals until field screening results indicate less than $75 \mathrm{ppm} \mathrm{TPH}$.

If the depth to bedrock is deeper than the vertical reach of the Geoprobe or if the Geoprobe is unable to penetrate the soil, then a backhoe will be used.

\subsection{DEFINE THE BOUNDARIES OF THE STUDY}

\subsection{Define the geographic areas of the field investigation.}

5.1.1. Define the geographic area within which all decisions must apply (in some cases this may be defined by the Corrective Action Unit)

The area identified as containing petroleum-impacted soil by the conceptual model. This area is expected to be contained in the immediate area of the former tank located at the north end of Building 24-50. This location has an estimated impacted area of 3.3 by 4 by $0.6 \mathrm{~m}$ ( 10 by 12 by $2 \mathrm{ft}$ ). This indicates a maximum volume of impacted soil of approximately $8 \mathrm{~m}^{3}\left(9 \mathrm{yd}^{3}\right)$. A non-rigorous calculation based on the formula prepared by Dragun, (1988) suggests a similar volume of petroleum-impacted soil.

\subsubsection{Specify the characteristics that define the population of interest}

The population of interest is the potential vertical and horizontal extent of petroleumimpacted soil from the ground surface to the bedrock. This area is defined as all soils that contain TPH in concentrations equal to or greater than $100 \mathrm{mg} / \mathrm{kg}$.

\subsection{Define the time frame of the decision}

\subsubsection{Determine the time frame to which the study data apply}

- The study data should be relevant with the length of time allowed for by the SAFER process under the Federal Facilities Agreement and Consent Order (FFACO) agreement. 
- Migration of petroleum product in the subsurface (if occurring) is assumed to be imperceptibly slow. This is based on minimal surface water infiltration and the constraint defined in the conceptual model.

\subsubsection{Determine when to collect data}

Field activities (data collection) are scheduled to take place in fiscal year 2002 after approval of the final SAFER work plan. Data will be collected at times that meet the security and safety constraints of the TTR site, and at times that weather conditions that allow adequate site access and safe working conditions.

\subsubsection{Define relevant time constraints}

The final Closure Plan deliverable deadlines have not been formally developed.

\subsection{Identify any practical constraints on data collection}

- Approval of the SAFER Plan and the Data Quality Objectives process by the NDEP.

- $\quad$ Equipment access, operation, and mobility around Building 24-50.

- Due to structural concerns, no excavation or sampling will be conducted beneath Building 24-50.

- If TPH contamination extends into bedrock no further sampling will be done.

- $\quad$ Site operations - TTR operational and security constraints. Access to the site may only be allowed when radar is not in operation, and when access is approved by Sandia National Laboratories.

- Meteorological events that may impact fieldwork activities.

- Availability of field equipment.

- Health and safety of workers.

6.0 DEVELOP A DECISION RULE - DEFINE A LOGICAL BASIS FOR CHOOSING AMONG ALTERNATIVE ACTIONS

\subsection{Specify the action level or preliminary action level for the decision}

Sufficient analytical data and process knowledge exists to support the conceptual model. The action level is $100 \mathrm{mg} / \mathrm{kg}$ TPH.

\subsection{Specify Tolerable Limits on Decision Errors}

The sampling approach relies on the collection of biased samples from areas with the greatest potential to be impacted by petroleum product; therefore, statistical analysis is not appropriate. 
7.0 OPTIMIZE THE DESIGN - OUTLINE A SAMPLING DESIGN, SPECIFYING THE OPERATIONAL DETAILS OF THE SAMPLING PLAN WHICH FALLS WITHIN THE PROJECTS CONSTRAINTS

\subsection{Develop general sampling and analysis design alternatives}

Sampling will be conducted using a Geoprobe core sampler with a sample interval of $0.3 \mathrm{~m}(1 \mathrm{ft})$. If the soil conditions encountered preclude the use of the direct-push sampler, a backhoe will be used to excavate the soil. Samples will be collected from the bucket or excavation as dictated by safety concerns. Analytical method and approach will follow that specified in Section 4.3 with the exception that a backhoe will be utilized to obtain the soil samples for screening and laboratory analysis.

\subsection{Select the most resource-effective design that satisfies all of the DQOs}

- Sample using PetroFLAG ${ }^{\mathrm{TM}}$ (or equivalent) test kit to identify the presence or absence of COPCs.

- Collect biased samples from the areas of highest field screening concentrations and submit for laboratory analysis using EPA Method 8015M for full scan TPH.

- After receipt and evaluation of field analytical results, collect samples at step-out locations, as needed, to define the vertical and horizontal extent of petroleumimpacted soil.

- Excavate soil to the lateral and vertical extent of petroleum-impacted soil and collect confirmation samples to verify that all soil impacted with TPH above $100 \mathrm{mg} / \mathrm{kg}$ has been removed.

\subsection{Document the operational details and theoretical assumptions of the selected design in the sampling and analysis plan}

Detailed documentation of sampling and analysis will be discussed in the SAFER Work Plan. 


\section{APPENDIX A-2 PROJECT ORGANIZATION}


THIS PAGE INTENTIONALLY LEFT BLANK

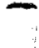

$-$

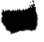

$-$

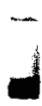

$-$

$-1$

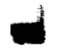

$-$

1

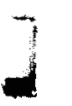

$d$

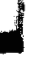

i

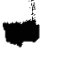

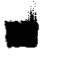




\section{PROJECT ORGANIZATION}

The U.S. Department of Energy, National Nuclear Security Administration Nevada Operations Office (NNSA/NV) Project Manager or Task Manager will serve as the primary point of contact for all activities conducted for this project. The NNSA/NV Project Manager is responsible for seeing that all activities conducted during the project fulfill the obligations of NNSA/NV, as described in the Federal Facility Agreement and Consent Order (FFACO, 1996) and the Nevada Division of Environmental Protection (NDEP) approved work plan. The NNSANN Project Manager will plan, authorize, and control project work so that activities are completed in accordance with the work plan on schedule and within budget. The NNSA/NV Project Manager will be the primary point of contact with the NDEP. The NNSANV points of contact for this project are as follows:

Project Manager: Janet Appenzeller-Wing

Telephone Number: (702) 295-0461

Task Manager: Kevin Cabble

Telephone Number: (702) 295-5000

The identification of the project Health and Safety Officer and the Quality Assurance officer can be found in both the Field Management Plan and the Site-Specific Health and Safety Plan. However, personnel are subject to change and it is suggested that the Project Manager be contacted for further information. 
THIS PAGE INTENTIONALLY LEFT BLANK

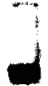
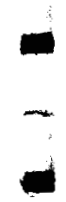

$-$

-

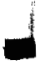

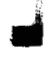

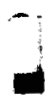

$-$

$-$

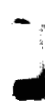

$-$

$-$

$+$

$+$

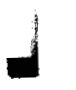

-

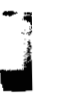

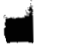




\section{APPENDIX A-3 SPILL NOTIFICATION FOR BUILDING 24-50 AT TTR}




\section{Bechtel Nevada}

Mailing address: P.O. Box 98521

Las Vegas, N 89793-8521

Express mail only: 2621 Losee Road

North Las Vegas, NV 89030-4134

1300-LS-98-0195

April 13, 1998

Kenneth A. Hoar, Director

Environmental Protection Division

DOE Nevada Operations Office

P. O. Box 98518

Las Vegas, NV 89193-8518

Subject: Contract No. DE-AC08-90NLV11718

TRANSMITTAL OF 30 DAY REPORT FOR NEVADA DIVISION OF EMERGENCY MANAGEMENT (NDEM) CASE NUMBER 980326-2728 TONOPAH TEST RANGE BULDING 24-50, R-24 GENERATOR STATION Project No. 04047

Enclosed is the 30 day report for an above-ground hydrocarbon release near Building 24-50, R-24 generator station at the Tonopah Test Range. On February 18, 1998 an older release was discovered during the investigation and clean-up of a non-reportable diesel release. The older release is in the area of the above-ground storage tank (AST) and piping that provides fuel for an emergency generator. The older release is believed to have been caused by a release from the AST system.

On February 18, 1998 an exploratory excavation was advanced at the site and soil samples were collected. Results indicated that the concentration of total petroleum hydrocarbons exceeded the State of Nevada action level of $100 \mathrm{ppm}$ of petroleum hydrocarbons (Nevada Administrative Code 445A.347). Notification of the release was sent to your office on March 25, 1998.

The site will be included as a Corrective Action Unit in the Federal Facilities Agreement and Consent Order (FFACO).

If you have any questions regarding this matter, please contact Sandra S. Simplicio at 295-4838.
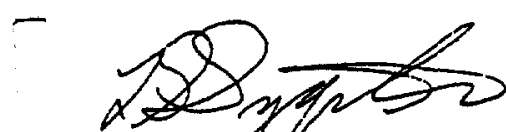

- L. S. Sygitowicz, Program Manager

Waste Management Program

- SSS:cjs

Subject Code: WMT3

cc: See page 2 
1300-LS-98-0195

K. A. Hoar

Page 2 of 2

April 13, 1998

Enclosures: as stated

cc w/ encs.

Correspondence Control, NLV008

J. L. Appenzeller-Wing, DOE/NV, M/S 505

K. J. Cabble, DOE/NV, M/S 505

D. L. Howard, DOE/NV, M/S 505

J. A. Dickinson, BN, NLV080

R. H. Guymon, BN, NTS327

B. D. Madsen, BN, NTS306

S. J. Nacht, BN, NTS306

D. Raco, BN, NTS250

C. J. Schwartze, BN, NTS207

S. S. Simplicio, BN; NTS207

C. A. Stowell, BN, NTS207

cc w/o encs.

D. L. Foster, BN, NLV080
W. E. Forston, KMI

J. W. Elliston, KMI

KMI Services

P. O. Box 871

Tonopah, NV 89049 


\section{DAY REPORT FOR ABOVE GROUND HYDROCARBON RELEASE \\ AT THE TONOPAH TEST RANGE BUILDING 24-50, R-24 GENERATOR STATION NEVADA DIVISION OF EMERGENCY MANAGEMENT (NDEM) \\ CASE NUMBER 980326-2728}

The site is located at the Tonopah Test Range, Nevada, in Section 25 of T2S R42E. On February 18, 1998, an older release was discovered during the investigation and clean-up of a non-reportable diesel release. The non-reportable release occurred on February 18, 1998, and was the result of a fuel gauge failure during maintenance on an emergency generator system. The older release is in the area of the above-ground storage tank (AST) and piping that provides fuel for an emergency generator. The older release is believed to have been caused by a release from the AST system.

On February 18, 1998, an exploratory excavation was advanced at the site. Soil samples were collected for Total Petroleum Hydrocarbons (TPH) for diesel, using U. S. Environmental Protection Agency method 8015 modified. Results indicated that the concentration of total petroleum hydrocarbons exceeded the State of Nevada action level of $100 \mathrm{ppm}$ of petroleum hydrocarbons (Nevada Administrative Code 445A.347). Notification of the release was sent to your office on March 25, 1998. NDEM Case Number 980326-2728 was assigned. A copy of the original Spill Notification Report is provided in Appendix A.

\section{Description of the Spill/Release of Petroleum Products}

a. Type of product released into environment: Diesel fuel

b. Quantity of product released: Unknown

c. Date and time of release: Unknown. The release was discovered on February 18, 1998.

d. Cause of release: The cause of the release is attributed to a fuel gauge failure during maintenance on an emergency generator system.

e. Distance to and location of closest well or reservoir used for drinking water purposes: The closest well, Main Well, is located approximately 4 miles northeast of the site.

2. Description of Action to be Taken or Completed

a. Soil testing laboratory, test method, and results: On March 18, 1998, two soil samples (Sample Numbers 11 and 12) were collected from the bottom of the excavation. The samples were analyzed for Total Petroleum Hydrocarbons (TPH), using U. S. Environmental Protection Agency method 8015 modified. Results are provided in the table below and Appendix B. 


\begin{tabular}{|c|c|c|}
\hline SAMPLE NUMBER & LOCATION & TPH (mg/kg) \\
\hline \hline 11 & Bottom of Excavation & $\begin{array}{c}5.1 \text { (gasoline) } \\
483 \text { (diesel) }\end{array}$ \\
\hline 12 & Bottom of Excavation & $\begin{array}{c}202 \text { (gasoline) } \\
7,130 \text { (diesel) }\end{array}$ \\
\hline
\end{tabular}

b. In situ contaminated soil treatment method, if applicable: Not applicable

c. Contaminated soil removal:

(1) Amount of soil removed: approximately 1.5 cubic yards of soil was excavated in the area of the recent non-reportable release.

(2) Total Petroleum Hydrocarbon concentration of soil removed: Not sampled

(3) Final disposition of removed soil: The excavated soil was placed on and covered with plastic and will be managed until the remedial alternative for the site is implemented.

(4) Date of soil removal: Initial removal of soil occurred on February 18, 1998.

d. Soil, groundwater, and air monitoring methods: Not applicable

e. Measures taken to correct and prevent the recurrence of this incident: Not applicable.

f. Consultant employed and scope of duties and responsibilities: Under the DOE/NV Environemental Restoration Program, Bechtel Nevada (BN) will be responsible for documenting all site activities, site characterization, remedial activities, removal of hydrocarbon contaminated soils, and reporting.

g. Contractors employed and scope of duties and responsibilities: BN, will provide project management, general construction, and laboratory services for the cited activities.

h. Results of tank tightness test, if any: Not applicable

i. Depict the location on an appropriate scale map: See Figure 1. 
1

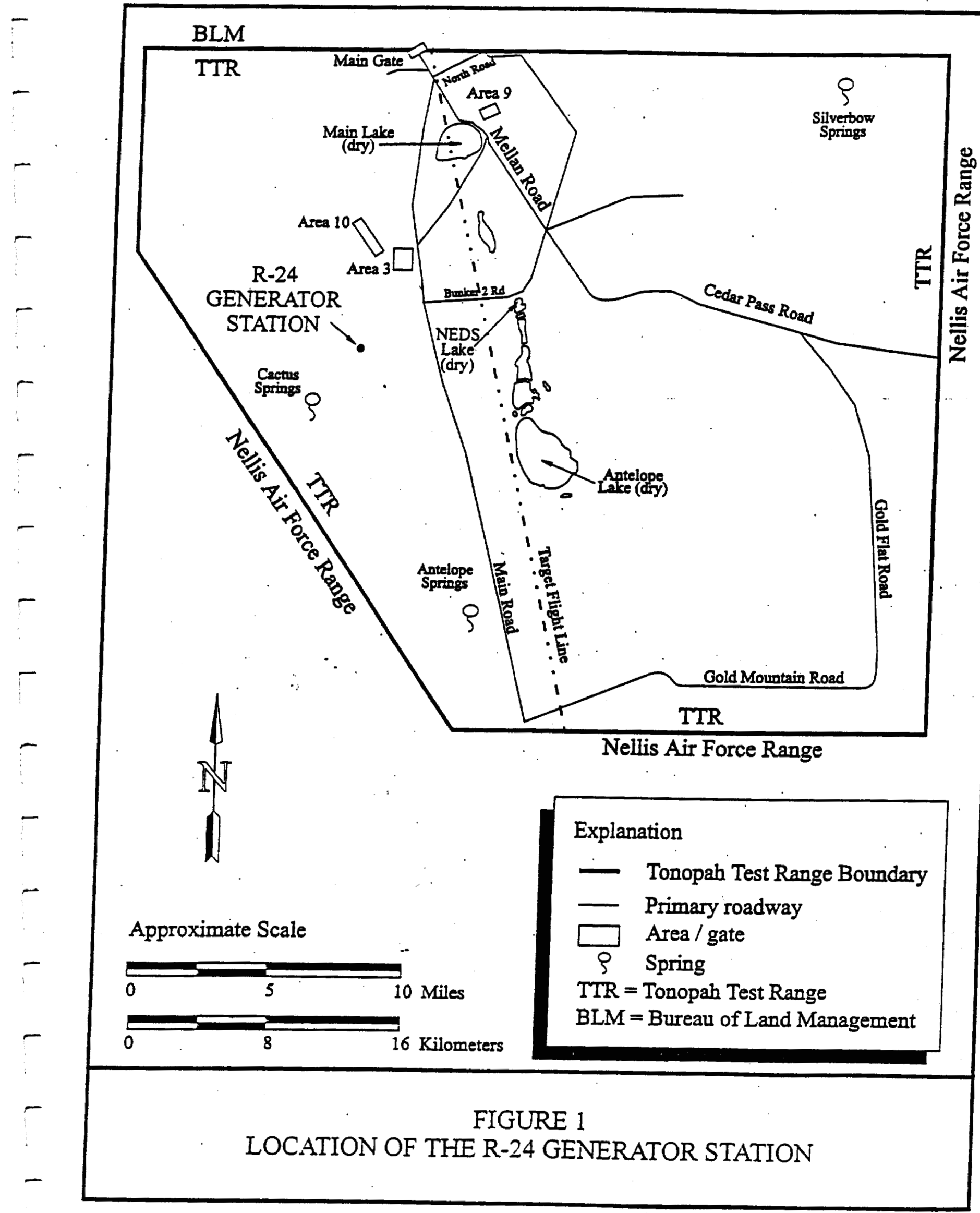




\section{APPENDIX A SPILL NOTIFICATION REPORT}




\section{SPILL NOTIFICATION REPORT}

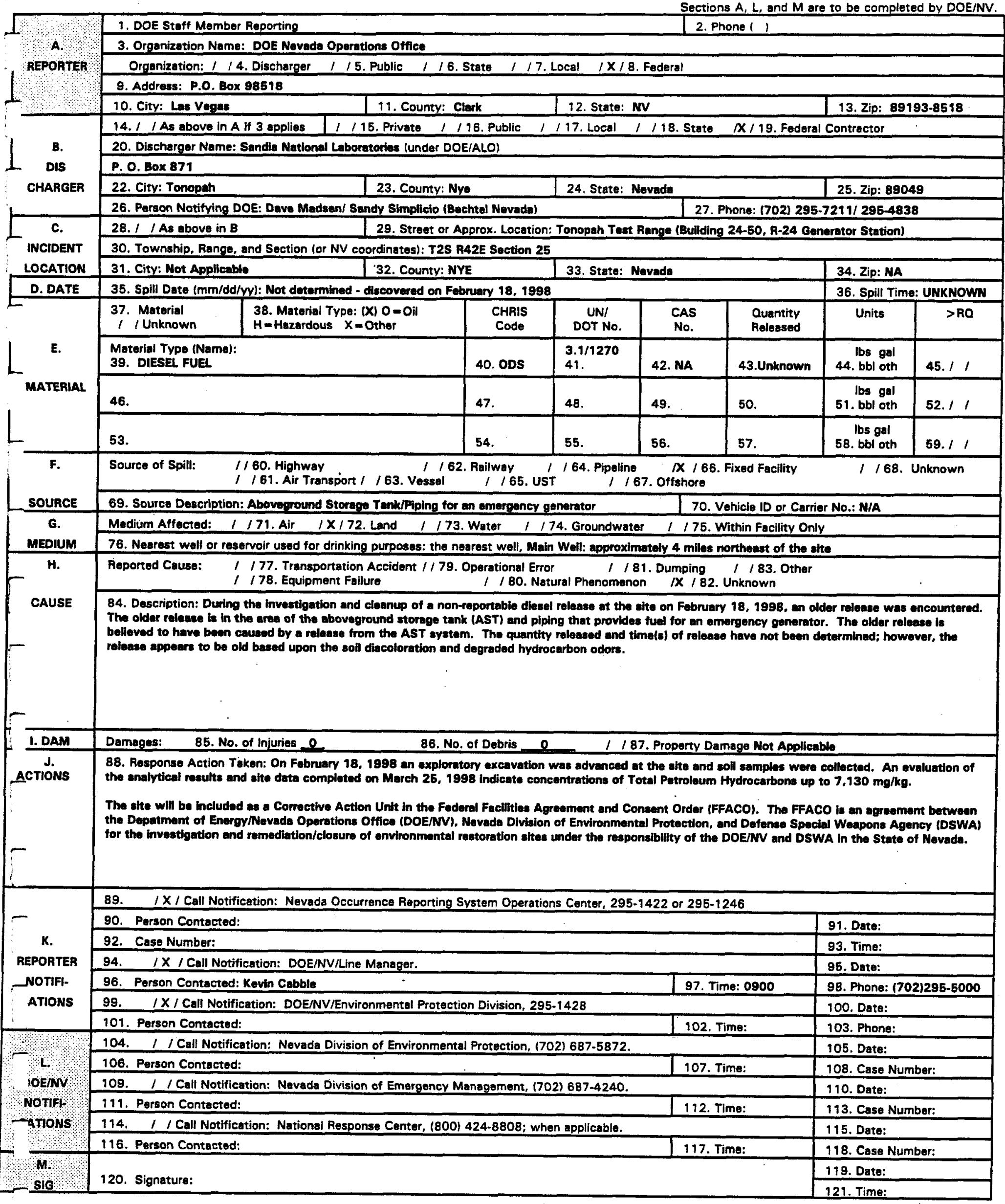




\section{APPENDIX B \\ LABORATORY ANALYTICAL RESULTS}




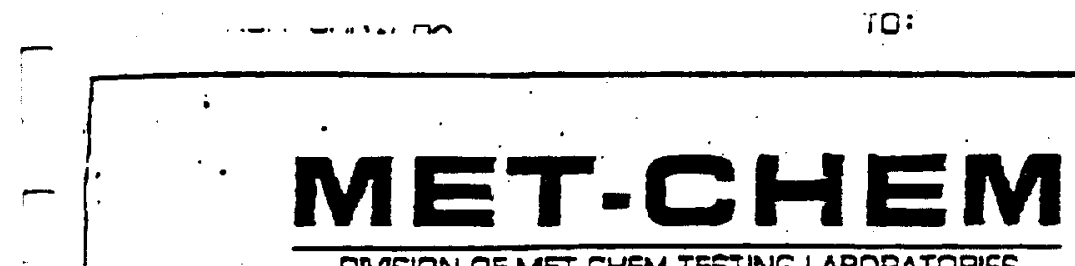

OMSIDN OF MET-CHEM TESTING LABORATOAIES,
- ATTN MR WILIIAM FORSTON SANDIA NATIONAL LABS/KMI PO BOX 871

- TONOPAH NV 89049

\section{WORK REOUESTED}

- Chemical Analysis per Hugh Temperature Modified, California Modified 8015 (8015) for Total Petroleum Hydrocarbons (TPH)

\section{DESCRIPTION OF SAMPLE}

Twelve (12) samples reported to be "Soil" and identified as 980219WF-, 2/19/98, Grab and:

- (1) $-1,03-58,1200$, West Wall

(2) $-2,03-58,1200, \mathrm{~S}$. Wall Under Foundation

(3) $-3,03-58,1200$, E. Wall

(4) $-4,03-58,1200$, E. Contr Ramp

(5) $-5,03-58,1200, \mathrm{~N}$. Wall Under Valve

(6) -6, 03-58, 1200, Wall Under Conerete Cube

- CHEMICAL ANALYSIS (8015)

(7) $-7,03.58,1200$, Bottom SW Comer

(8) $-8,03-58,1200$, sW Comer Bottom

(9) -9, 03-58, 1200, Center Bottom Hole (10) $-10,03-58,1200, N$. Bottom Hole

(11) -11, R-24, 0900, Generator Bldg., Gray MTL

(12) -12, R-24, 0900, Generator Bldg.

INVOICE NO: 8544

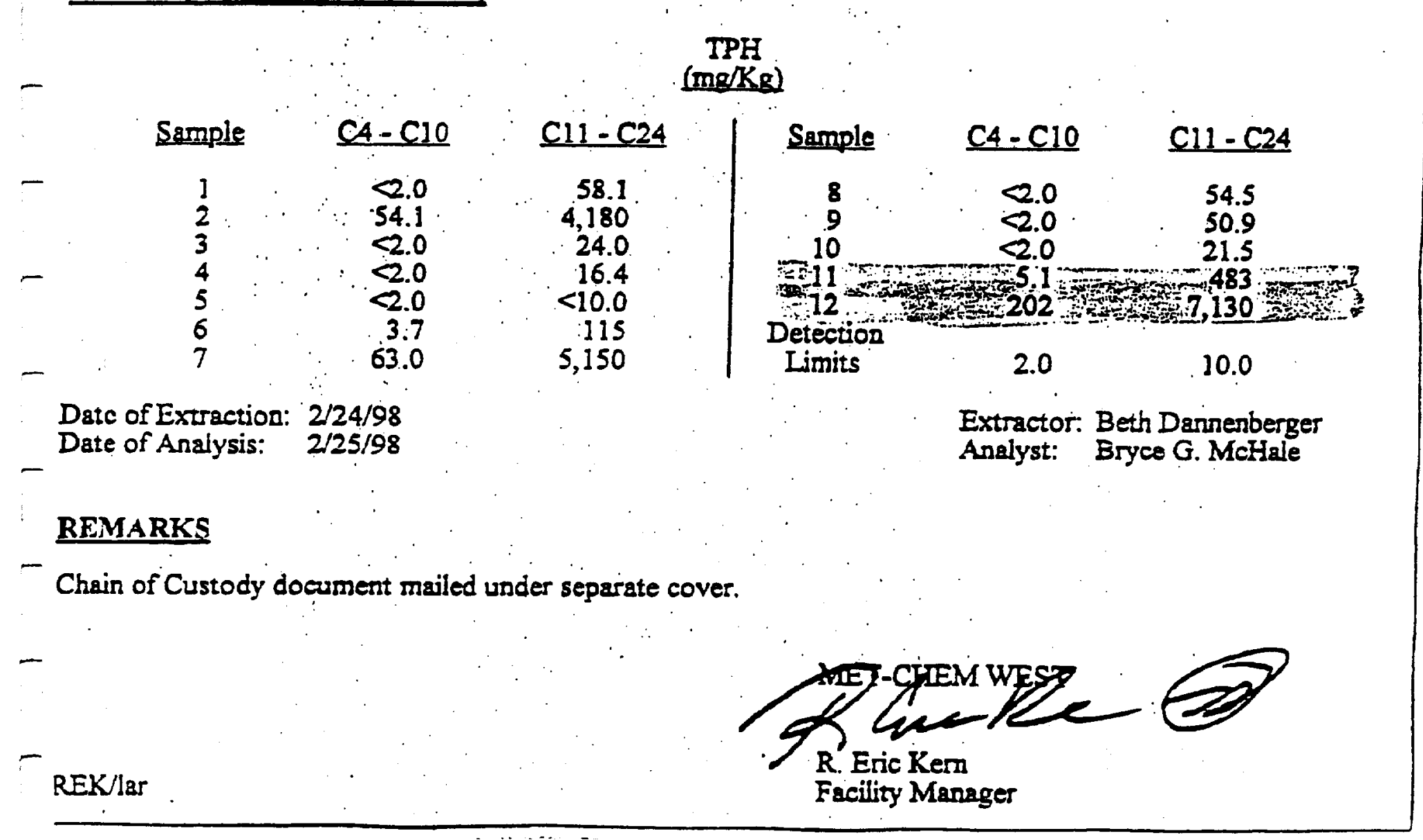


KMI ENVIRONMENTAL MANAGEMENT MEMO

DATE: 03/25/98

TO: DAVE MADSEN

FROM: WILIAM FORSTON

RE: DIESLI SPII — BUILDING 24.50, R-24 GENERAIOR STATION

Herc are the events that took place on $2 / 28 / 98$.

John lerras and Scolt Hermann were lrying to get the generator working at R-21. At approximately 1030 hours the generator was started and seott Hermann witnessed the fuel gage on top of the tank break. The gencrator was Immediately shut down and Scott and Joln began cleanup of the fucl that came down the sides of the tank. The ruel loss was estinated at less than 1 gallon. Approximately 20 to 30 gallons of soil was jmmediately removed. I arrived with a PID at approximately 1100. 'l'he bottos of the excavated area read between 500-800 ppm on the PID. $\Lambda$ bag sample taken at a depth of approximately 2.5 feet indicated $>2500$ ppm. In talking to John Terras he sald that this has been the location of suel lanks for more than 30 years, mostly without secondary containment. To try and determine the extent of the contamination we moved the fuel lank, brought a back-hoe to the location, and removed several buckets of soll. We then discovered evidence of prior spi21s al the location (blaskish gray almost tar like material in the hole several feet down again with PID mensurements in the $700-900 \mathrm{ppm}$ range. At this time approximately 1.5 yards of soil has been removed from the spi.jl site. DOE was contacted and is going to accomplish a hislorical spill isvestigation.

Two TFH samples modified 8015 were collected from the spill site with results for the first indicoting $5.1 \mathrm{mg} / \mathrm{kg} \mathrm{TPH}(\mathrm{C} 4-\mathrm{ClO})$ and $483 \mathrm{mg} / \mathrm{kg}$ (C11-C24) the second sample's results indicated $202 \mathrm{mg} / \mathrm{kg}$ TPH (C4-ClO) and $7,130 \mathrm{mg} / \mathrm{kg}$ l'PH $(\mathrm{C11-C24)}$.

William Forfton, KMI Services
Env Mgr/Induptrial Hygienist. 


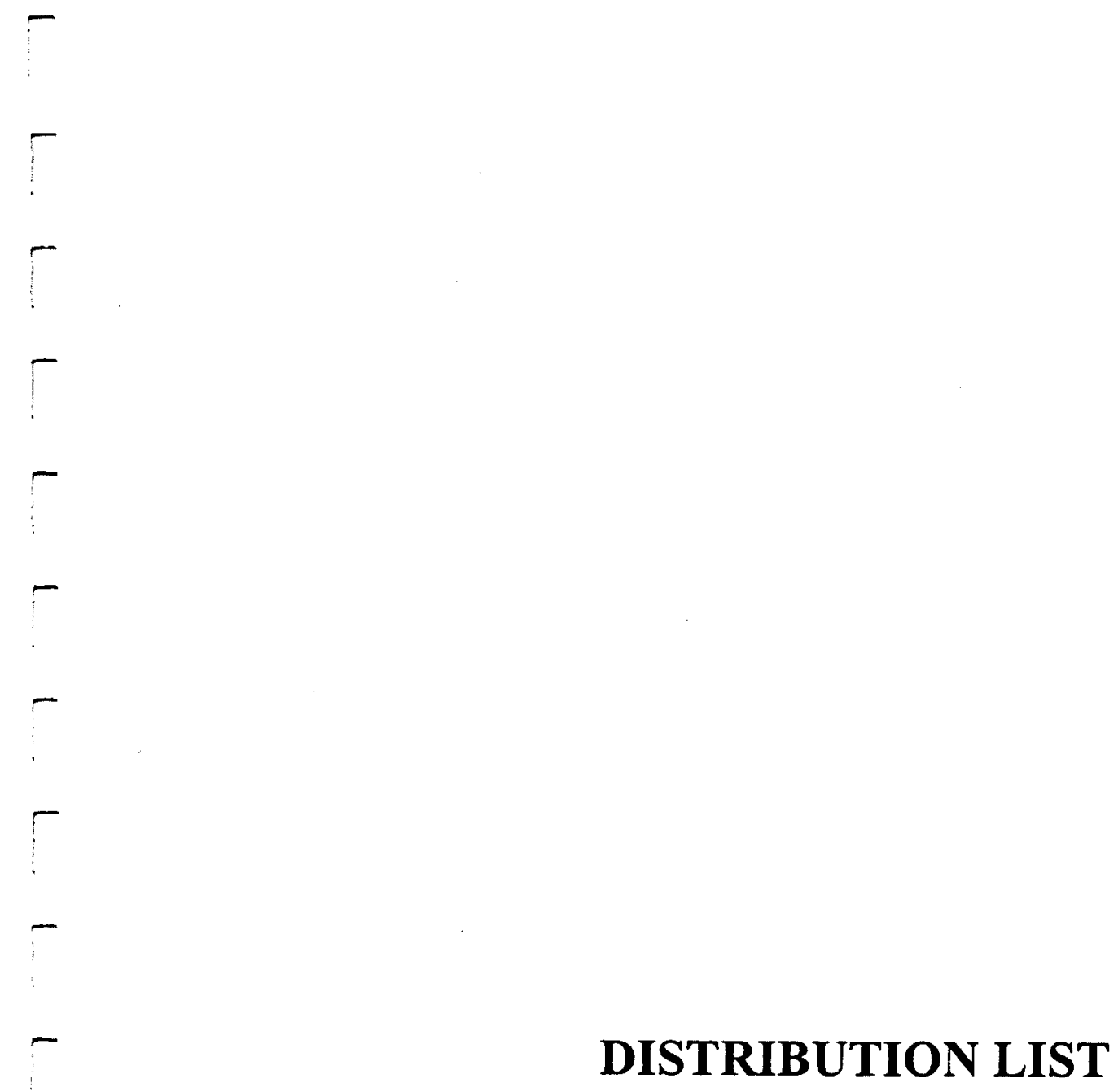


THIS PAGE INTENTIONALLY LEFT BLANK

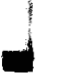

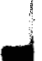

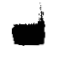

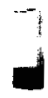

$+$

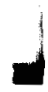

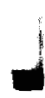

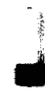

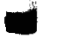

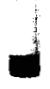

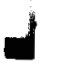

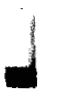

a 


\section{DISTRIBUTION LIST}

*Provide copy of initial distribution of Revision 0; remainder of list gets Revision 0 if approved without changes. The entire list receives Revision 1, if issued.

\section{Nevada Department of Environmental Protection}

Paul Liebendorfer

Bureau of Federal Facilities

Division of Environmental Protection

333 W. Nye Lane, Room 138

Carson City, NV 89706-0866

Supervisor, Las Vegas Office

Bureau of Federal Facilities

Division of Environmental Protection

555 E. Washington, Suite 4300

Las Vegas, NV 89010-1043
2 (Controlled)*

1 (Controlled) $^{*}$

1 (Uncontrolled)*

Janet Appenzeller-Wing

Environmental Restoration Division

U.S. Department of Energy

National Nuclear Security Administration

Nevada Operations Office

P.O. Box 98518 , M/S 505

Las Vegas, NV 89193-8518

Kevin Cabble

Environmental Restoration Division

1 (Uncontrolled)*

U.S. Department of Energy

National Nuclear Security Administration

Nevada Operations Office

P.O. Box 98518 , M/S 505

Las Vegas, NV 89193-8518

Sabrina Lawrence

Environmental Restoration Division

U.S. Department of Energy

National Nuclear Security Administration

Nevada Operations Office

P.O. Box 98518 , M/S 505

Las Vegas, NV 89193-8518 


\section{DISTRIBUTION LIST (continued)}

\section{U.S. Department of Energy (continued)}

Manager, Northern Nevada

1 (Uncontrolled)

FFACO Public Reading Room

Nevada State Library and Archives Federal Publications

100 North Stewart Street

Carson City, NV 89701-4285

U.S. Department of Energy

1 (Controlled \&

National Nuclear Security Administration

1 Uncontrolled)

Nevada Operations Office

Public Reading Facility

P.O. Box 98521 , M/S NLV040

Las Vegas, NV 89193-8521

U.S. Department of Energy

1 (Uncontrolled

National Nuclear Security Administration

Nevada Operations Office

Technical Information Resource Center

P.O. Box 98518 , M/S 505

Las Vegas, NV 89193-8518

U.S. Department of Energy

Office of Scientific and Technical Information

1 (Uncontrolled \&

P.O. Box 62

Oak Ridge, TN $37831-0062$

\section{Bechtel Nevada}

Correspondence Control

1 (Uncontrolled)*

Bechtel Nevada

P.O. Box 98521 , M/S NLV008

Las Vegas, NV 89193-8521

Environmental Management Library

1 (Uncontrolled)*

Bechtel Nevada

1 electronic copy)

P.O. Box 98521 ; M/S NLV080

Las Vegas, NV 89193-852l 
Bechtel Nevada (continued)

Kevin Campbell

1 (Uncontrolled)*

Bechtel Nevada

P.O. Box 98521 , M/S NTS306

Las Vegas, NV 89193-8521

Ann Heidema

1 (Uncontrolled)

Bechtel Nevada

P.O. Box 98521 , M/S NLV022

Las Vegas, NV 89193-8521

Ronald Jackson

1 (Uncontrolled)*

Bechtel Nevada

P.O. Box 98521 , M/S NTS306

Las Vegas, NV 89193-8521

Wayne Johnson

Bechtel Nevada

1 (Uncontrolled)*

P.O. Box 98521 , M/S NTS306

Las Vegas, NV 89193-8521

Steve Nacht

Bechtel Nevada

1 (Uncontrolled)*

P.O. Box 98521 , M/S NTS306

Las Vegas, NV 89193-8521

\section{IT Corporation}

Lynn Kidman

IT Corporation

P.O. Box 93838 , M/S 439

Las Vegas, NV 89193-8521

Garry Romano

IT FFACO Support Office

IT Corporation

P.O. Box 93838 , M/S 439

Las Vegas, NV 89193-8521

1 (Uncontrolled)*

1 (Controlled) 


\section{DISTRIBUTION LIST (continued)}

\section{U.S. Air Force}

E. V. Hopper

U.S. Air Force

Nellis Air Force Base

Las Vegas, NV.

Air Warfare Center

RMO/RML

1 (Controlled)*

Nellis Air Force Base

Las Vegas, NV.

U.S. Air Force Liaison Office

National Nuclear Security Administration

3 (Controlled)*

Nevada Operations Office

Las Vegas, NV.

Northern Range Commander

Tonopah Test Range

1 (Uncontrolled)*

Tonopah, NV.

\section{Sandia National Laboratory}

Vern Gabbard

Sandia National Laboratory

1 (Uncontrolled)*

Tonopah Test Range

Tonopah, NV. 